\title{
THE LEGAL FRAMEWORK OF TRADE BETWEEN PLANNED AND MARKET ECONOMIES: THE SOVIET-AMERICAN EXAMPLE*
}

\author{
HaRold J. Berman'
}

\section{INTRODUCTION}

State trading differs in kind, and not only in degree, from other forms of governmental control of international trade. By tariffs, quotas, prohibitions, exchange restrictions, subsidies, credits, and the like, a government may limit or encourage the conduct of trade by private businessmen; nevertheless, despite such controls, the distinction between the world of commerce, built on market principles, and the world of politics, built on other principles, remains a real one. When state organizations themselves conduct trade, however, the distinction becomes blurred and in some cases loses its reality entirely.

This fact becomes apparent when one considers the most extreme form of statetrading system, that of integrally planned economies of the Soviet type, all of whose foreign trade (including not only export and import, but shipping, banking, insurance, and the like) is conducted by state organizations. Indeed, the phrase "state trading," which implies the co-existence of private trading, does not fully express the union of economics and politics in Soviet foreign trade, or, for that matter, in Soviet domestic trade. The Soviet type of foreign trade system thus reveals the inadequacy of conventional concepts and traditional institutions which were devised to deal with the situation in which the state organizations of a country appear alongside its private firms and hence can be assimilated, in our thinking, to such firms.

If the foreign trade systems of planned economies compel us to think about statetrading organizations in different terms, where are such terms to be found? They can only be discovered through analysis of the actual workings of the foreign trade

- The present article is adapted from the writer's General Report to the UNESCO Conference on Legal Aspects of Trade Between Planned and Free Economies, Rome, February 1958. Assistance in research by Ralph Nader, LL.B. 1958, Harvard University, and A. Joshua Sherman, LL.B. 1957, Harvard University, under grants of the Committee on Research and Development of Harvard University, is gratefully acknowledged. A condensed version of this article was presented at the annual meeting of the American Society of International Law, Washington, D.C., May I, 1959, and will be printed in a forthcoming volume of that Society's Proceedings.

+B.A. 1938, Dartmouth College; M.A. 1942, LL.B. 1947, Yale University. Professor of Law, Harvard University; Research Associate and Member, Executive Committee of the Russian Research Center, Harvard University. General Rapporteur, UNESCO Conference on Legal Aspects of Trade Between Planned and Free Economies, Rome, February 1958; Recipient of Rockefeller Foundation grant, 195657, for study in Europe of legal and institutional framework of trade between communist and noncommunist countries. Author, Justice in Russia: AN INterpretation of Soviet LAw (1950), [with Boris A. Konstantinovsky] Soviet Law in Action: The Recollected Cases of a Soviet Lawyer (x953), [with Miroslav Kerner] Soviet Military Law and Administration (I955), and other books. Contributor to periodicals. 
systems of planned economies and of the alternative methods of dealing with them which have been developed by private traders and governments of market economies.

For purposes of such analysis, it may be useful to undertake a case study of trade relations between the Soviet Union, which is an extreme type of planned economy, and the United States, whose foreign trade is, in general, less strictly controlled by governmental authorities than that of any major country in the world. Despite the special political and economic aspects of the case selected-and, in part, just because of those special aspects-such a study may shed light on the problems of developing an adequate framework for trade relations between planned economies and countries whose foreign and domestic trade is conducted primarily by private businessmen. operating largely on the basis of market conditions. Indeed, the example of SovietAmerican trade illuminates the problems of state trading in general by bringing to. the foreground questions of political and economic philosophy which are present, though not always so apparent, whenever any state conducts international trade.

\section{I}

\section{The Soviet System of Foreign Trade ${ }^{x}$}

Three principal characteristics distinguish the Soviet system of foreign trade from other trading systems. ${ }^{2}$ The first is that Soviet foreign trade is operated and administered exclusively by state agencies. The second is that Soviet foreign trade is conducted on the basis of integrated national economic planning. The third is that Soviet foreign trade and Soviet national economic planning are under the direction of a government which is led by a Communist Party. Although these three characteristics are closely interrelated, each of them gives rise to a distinct set of problems.

\section{A. Problems Arising from the Operation and Administration of Soviet Foreign Trade Exclusively by State Agencies}

The operation and administration of Soviet foreign trade is designated by the Soviet

\footnotetext{
${ }^{1}$ Scholarly literature in English on the Soviet system of foreign trade is very skimpy. ALEXANDER Baykov, Soviet Foreign Trade (1946), and Mikhail V. Condoide, Russian-American Trade (I947) are sketchy and out of date. General books on the Soviet economy usually subordinate the treatment of the institutional aspects of Soviet foreign trade. However, HArry Schwartz, Russin's Soviet Economy c. I4 (2d ed. I954), contains valuable information. Also Michate L. Hoffman, Problems of EAST-WeSt TrADE (Carnegie Endowment for International Peace, International Conciliation No. 5II, I957), and Raymond F. Miresell \& J. N. Behrman, Financing Free World Trade with the SinoSoviet Bloc (1958), are useful, though brief. A valuable compendium of the legal aspects of Soviet foreign trade is a mimeographed German monograph, CarL-Hans Bütow, Das gegenwn̈rtige innerSTAATLICH GEREgELTE AUSSENHANDELSRECHT DER UDSSR UNTER BERÜCKSICHTIGUNG DER ZWISCHENSTARTLICHEN VERTRÄGE (I956).

3 The term Sovict system of foreign trade is used to refer to the system of the Soviet Union. Becauseof the special kind of communist system established in Yugoslavia, and also because of certain differencesin the organization of foreign trade among the other communist countries, it is not possible to distinguish merely between communist and noncommunist trading systems. To speak of "Eastern" and "Western" systems is even more misleading. The term "communist" poses certain difficulties, because of the doctrine that the Soviet Union is now in the stage of "socialism," and is only gradually moving toward the establishment of full "communism." To speak of the Soviet system as a socialist system, however, is confusing to those who identify socialism with the type of political and economic organization which exists, for example, in Sweden. The term "communist" is used throughout this article to refer to countries in which the government is led by a Communist Party.
} 
Constitution, by Soviet decrees, and by Soviet writers as a "state monopoly." In this respect, foreign trade does not differ from most of the other branches of the Soviet economy. ${ }^{4}$ However, the Soviet state cannot control the terms and conditions of foreign trade to the same extent that it can control the terms and conditions of its domestic economic activities. If it is successfully to maintain extensive economic connections with foreign countries, it must adapt its methods of trade to foreign requirements. ${ }^{5}$

Of the many particular problems of adjustment which have arisen, a few may be singled out as particularly significant from the point of view of the development of

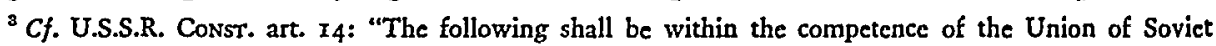
Socialist Republics in the form of its highest organs of state authority and its organs of state administration: . . . h) foreign trade on the basis of state monopoly." A 1922 decree states: "The forcign trade of the RSFSR shall be a state monopoly. The state forcign trade monopoly shall be realized by the People's Commissariat of Foreign Trade." Sbornik Uzakonenil [Collection of Laws] no. 24, art. 266 (1922). The R.S.F.S.R. is the largest of the constituent republics of the Soviet Union; in 1922, the Soviet Union had not yet been constituted as such. The People's Commissariat of Forcign Trade of the Soviet Union was established in I924. The People's Commissariats were renamed Ministries in I946.

The essence of the state monopoly of foreign trade, according to a resolution of the Plenum of the Central Committee of the Communist Party, of October 5, 1925, "consists in the fact that the state itself realizes the conduct of foreign trade through a specially created organ (the People's Commissariat of Foreign Trade)." The state "establishes what organizations, in what spheres and in what amounts, can carry on immediate operations in foreign trade; proceeding from the tasks of advancing the economy and socialist construction, it defines, by means of the export-import plan, what goods and in what quantities may be taken out of the country and what can be brought into it; by means of a system of licenses and contingents it immediately regulates import and export and the operations of the forcign trade organizations." I Direktivy KPSS I Sovetskogo Pravitel'stvo po Khoziastvennym Voprosam 1917-28 [DIRECTIVES OF THE CPSU AND THE SOVIET GOVERNMENT ON ECONOMIC Questions, 1917-28], at 555 (1958).

"Thus the state monopoly of foreign trade," writes a recent author, after quoting the above statements, "should be defined as the concentration in the hands of the state, as represented by organs of state administration specially authorized therefor, of the entire matter of the conduct of forcign trade." Pozdniakov, Pravovye Voprosy Gosudarstuennoi Monopolii Vneshnei Torgouli v SSSR [Legal Questions of the State Monopoly of Foreign Trade in the U.S.S.R.], in D. M. Genkin (ED.), Pravovye Voprosy VNESHNEI Torgovi SSSR s Evropeiskimi Stranami Narodnol Demokratsil [Legal Questions of Foreton Tradb of the U.S.S.R. with European Countries of People's Democracy] 5, 9 (1955).

It should be noted that in the I920's, the phrase "state monopoly" did not signify that all forcign trade was to be conducted by "organs of state administration." Under the 1922 decree and the 1925 Party definition quoted above, the state could authorize private and cooperative organizations to conduct foreign trade. In fact, a good deal of Soviet forcign trade at that time was conducted by the Central Union of Cooperatives (Tsentrosoiuz). The R.S.F.S.R. Civil Code, which was enacted in 1922, and which is still in force, states: "All persons, juridical and physical, residing in the RSFSR shall participate in foreign trade only through the medium of the state as represented by the Pcople's Commissariat of Foreign Trade. Independent appearances on forcign markets shall not be permitted except in instances specially indicated by law and only under the supervision of the Pcople's Commissariat of Foreign 'Trade." R.S.F.S.R. CIvIL CODE art. 17 (1956) (U.S.S.R.). A recent article indicates that since 1957, Tsentrosoiuz has once again been active in Soviet foreign trade. See Kaplun, Mezhdunarodnye Torgovye Sviazi Tsentrosoiuza [International Trade Links of Tsentrosoiuz], Vneshiaia Torgovlia, No. 3, 1959, p. 10.

"This was not true of the period of the I920's, under the so-called New Economic Policy, when a considerable amount of private domestic trade and a certain amount of private production was permitted. The distinctive term "state monopoly," which is used only to describe the foreign trade system, is, therefore, largely of historical significance. It remains true, however, that foreign trade is more highly centralized than many other branches of the Soviet economy. Cf. infra note 127 .

The Soviet Union traded in 1957 with 53 countries. Its total volume of exports and imports was over $\$ 8,000,000,000$, of which over $\$ 2,000,000,000$ was with noncommunist countrics. MiNisterstvo VNEsHNEt Torgovli SSSR [Ministry of Foreign Trade of the U.S.S.R.], VNeshninia Torgovlia Soluza SSR za

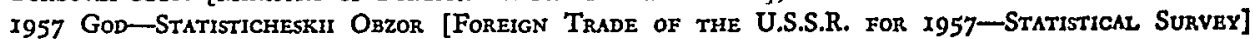
7-10 (1958). 
an adequate legal framework for trade between communist and noncommunist countries. One is the problem of sovereign immunity. It is in the interest of the Soviet state to take advantage of the doctrine of sovereign immunity as developed in other countries. On the other hand, it is also in the interest of the Soviet state not to deter foreign firms from trading with the Soviet Union through fear that the defense of sovereign immunity will be used to defeat any claims which may arise.

A second problem arises because certain legal concepts and institutions developed for Soviet domestic trade conflict with legal concepts and institutions generally accepted in the non-Soviet world. It is in the interest of the Soviet state that its commercial arrangements with foreign firms conform to its own law. On the other hand, the Soviet state cannot expect foreign firms easily to accept Soviet law where it differs sharply from the common commercial standards of the international business community.

A third problem relates to procedures for settlement of disputes. It is in the interest of the Soviet state to avoid litigation in foreign courts or foreign arbitral tribunals by the inclusion in foreign trade contracts of a clause referring disputes to arbitration in Moscow. But a non-Soviet trader asked to sign such a clause will question whether the Soviet arbitration tribunal is itself not part of the state monopoly of foreign trade and hence inherently partial to the Soviet cause.

In the course of four decades of experience in international trade, the Soviet state has made serious efforts to resolve these and other similar problems in a manner acceptable both to it and to its trading partners. To say that these efforts have been to a considerable extent successful is not to deny the need for further adaptations and adjustments on the Soviet side. At the same time, the Soviet system of foreign trade, as it has actually developed, compels a revaluation of some of the oversimplified concepts of state trading which have existed in the non-Soviet world.

The Soviet leadership understood from the outset that the state monopoly of foreign trade does not require that foreign trade be conducted by the state itself in its own name. The state may realize its monopoly by authorizing or establishing various agencies to carry on foreign trade in their own names, under state supervision. By allocating a relatively small degree of independence to these agencies, the Soviet state has been able to achieve a relatively high degree of flexibility in adapting its trading methods to the international commercial and legal order within which it must live.

To understand the extent to which Soviet state trading agencies are independent or dependent and to evaluate the degree of flexibility and of rigidity in their adaptations to international conditions, it is necessary to analyze in some detail the organizational structure of Soviet foreign trade as a whole.

The administration and operation of Soviet foreign trade is in the hands, chiefly, of three agencies: the Ministry of Foreign Trade of the Soviet Union and its trade delegations (torgpredstva $a^{6}$ ), a number of foreign trade "combines" (ob"edineniia 7 ),

- An abbreviation for torgovye predstavitel'stva; the singular is torgovoe predstavitel'stvo, or in abbrevi2tion, torgpredstuo.

"The singular is $o b$ "edinenoe. A more literal translation would be "union." A special term is needed 
and the All-Union Chamber of Commerce.

\section{Ministry of Foreign Trade}

As part of the Council of Ministers of the Soviet Union, ${ }^{8}$ the Ministry of Foreign Trade plans Soviet foreign trade within the limits of over-all national economic plans, drafts trade agreements with foreign states, works out and administers tariff policies, issues licenses for export and import of goods, and directs the work of its trade delegations and of the foreign trade combines. ${ }^{\circ}$

A superficial reading of the list of powers and functions of the Ministry of Foreign Trade might leave the impression that they are not essentially different from the powers and functions of corresponding ministries of West European countries. The basic differences become apparent, however, when attention is given to the fact that the trade delegations and the foreign trade combines whose activities the Ministry plans and directs are state agencies subordinate administratively to the Ministry itself.

The trade delegations appear on foreign markets as representatives of the Soviet state as such. They are a component part of the diplomatic corps of the Soviet Union abroad; at the same time, they have virtually unrestricted power to conclude trade contracts with foreign firms in the name of the Soviet state. ${ }^{10}$ Soviet writers have characterized them as "a new type of agency appropriate only to a socialist state and created for the realization abroad of the monopoly of foreign trade."11

The Soviet trade delegate-i.e., the chief of the trade delegation-is almost invariably, if not invariably, an official of the Ministry of Foreign Trade, and the other members of the trade delegation are often officials either of the Ministry or of foreign trade combines or of domestic state industrial organizations.

The Soviet trade delegation is not a legal entity under Soviet law; it is not responsible for its debts and cannot sue or be sued. In the absence of treaty provision to the contrary, the trade delegation may, and generally does, invoke the doctrine of sovereign immunity to avoid the jurisdiction of foreign courts. ${ }^{12}$ The United States has expressly excluded Soviet trade delegations from entry, on the ground of their sovereign immunity. ${ }^{13}$

to distinguish the type of organization used to carry on foreign trade from other types of operative state organizations used in Soviet domestic industry and trade, which are called predpriiatiia (literally, "enterprises").

${ }^{8}$ The Council of Ministers of the Soviet Union is "the highest executive and administrative organ of state authority of the U.S.S.R." U.S.S.R. CoNST. art. 64. It is charged, inter alia, with "taking steps for realizing the national economic plan and the state budget and for strengthening the system of moncy and credit." Id. art. 68. The Council of Ministers is, technically, the Government of the Sovict Union.

${ }^{\circ}$ Cf. A. M. Smirnov \& N. N. Llubimov (Eds.), VNeshniaia Torgovlia SSSR [Foreign Trade of the U.S.S.R.] 77 (x954), where a somewhat more elaborate list of powers and functions is given.

${ }^{10} \mathrm{Cf}$. Statute on Trade Delegations and Trade Agencies of the USSR Abroad, Sobranie Znkonov SSSR [Collection of LAwS of THE U.S.S.R.] no. 59, art. 354 (I933).

I1 SMIRNov \& Liubimov (EDs.), op. cit. supra note 9, at 78 .

${ }^{12}$ Cf. Fensterwald, Sovereign Immunity and Soviet State Trading, 63 Harv. L. Rev. 6r4, 634-39 (I950). Provisions limiting the immunity of Soviet trade delegations may be found in commercial treaties between the Soviet Union and other communist countries. Pozdniakov, stipra note 3, at 29-3x. Cf. 1934 Anglo-Soviet Treaty. Fensterwald, supra at 635 .

${ }^{23}$ See infra 518. 


\section{Foreign trade combines}

A Soviet foreign trade combine, on the other hand, is a juridical person. It may acquire rights in property in its own name, incur obligations, and sue and be sued $;^{14}$ it is responsible for its debts out of those assets which are within its power of free disposition. ${ }^{15}$ It receives a charter which enumerates its powers and declares the amount of its chartered capital. ${ }^{10}$ The Soviet state-i.e., the treasury or fisc-

14 Cf. R.S.F.S.R. Civir CODE art. I3 (1956) (U.S.S.R.): "Juridical persons are such combines of persons and such institutions or organizations as may, in their own name, acquire rights in property, incur obligations, and sue and be sued in courts."

${ }_{15}$ The limitation of the liability of foreign trade combines to property within their power of free disposition is said to be based on general Soviet law as well as on Soviet trade treaties and agreements with foreign countries. The general law cited is R.S.F.S.R. Crvil Code art. x9 (r956) (U.S.S.R.). The SovietDanish treaty of August 17,1946 , is also quoted as follows: "Liability for any trade transactions, concluded without the guarantee of the Trade Delegation by any state economic organizations of the USSR which under Soviet legislation exercise the rights of independent juridical persons shall be borne by the aforementioned organizations only, and execution under these transactions may be taken only against their property." Other Soviet treaties have similar provisions. Cf. Genkin, Pravovoe Polozhenie Vsesoiuznykh Vneshne-Torgovykh Ob"edinenii, [The Legal Status of All-Union Foreign Trade Combines], in GeNkiN (ED.), op. cit. supra note 3 , at $53,7 \mathrm{r}$. Genkin adds: "Concerning the property of foreign trade combines upon which creditors of the combine may levy compulsory execution, the charters of the combine rely on general legislation concerning the property liability of state organizations." Ibid. Cf. charter of Sudoimport art. 3 , infra note 16 . This legislation excludes certain types of property from execution (land, buildings, machinery, and, in general, fixed capital), and in general permits execution on working (turnover) capital (money, claims, accounts receivable, raw materials, fuel, finished goods, etc.). $C f$. G. Kaliuzhnaia, Pravovye Formy MonopoliI Vneshnei Torgovli SSSR I IkH Istoricheskom Razvitil [Legal Fords of the Monopoly of Foreign Trade of the U.S.S.R. in their Historical Development] r33 (r95x).

${ }^{10}$ A typical charter of a foreign trade combine is the following charter of Sudoimport, which may be found (in Russian) in the monthly journal of the Ministry of Foreign Trade, Vneshniaia Torgovlia, No. 8, I954, p. 40:

\section{CHARTER OF THE ALL-UNION EXPORT-IMPORT COMBINE "SUDOIMPORT" General Regulations}

I. The All-Union Export-Import Combine "Sudoimport" is instituted for the carrying out of operations in the import, export and repair of ships abroad.

2. The All-Union Combine "Sudoimport" is an independent economic organization, possessing the rights of a juridical person, which acts on principles of economic accountability.

3. The All-Union Combine "Sudoimport" is liable, in its operations and obligations, with that part of its own property upon which, in conformity with current legislation in the U.S.S.R., execution may be levied.

The State does not bear responsibility for the operations and obligations of the All-Union Combine "Sudoimport."

The All-Union Combine "Sudoimport" does not bear responsibility for claims against the State, its organs, or other organizations.

4. The All-Union Combine "Sudoimport" resides in Moscow.

5. The All-Union Combine "Sudoimport" has a round seal, with its name and mark in the center of a hexahedron of two letters "SI," one inside the other.

f. The All-Union Combine "Sudoimport":

\section{Functions}

a) carries on operations for the export from the U.S.S.R. and sale in foreign markets of ships;

b) carries on operations for the import of ships into the U.S.S.R.;

c) carries on operations for the repair and re-equipment of ships abroad;

d) participates in the elaboration and carrying out of measures for the improvement of import and export operations in goods within its nomenclature;

c) participates in the elaboration, within the prescribed order, of standards and technical conditions for the goods within its nomenclature;

f) studies foreign markets, as well as achievements in production and trade techniques of goods which relate to the nomenclature of the Combine. 
is not liable for the obligations of the combine, and it is not liable for the obligations of the Soviet state or of any state organization other than itself.

Each of the Soviet foreign trade combines possesses a monopoly of foreign trade transactions in a particular sphere of the economy. Thus, for example, all Soviet exports and imports of lumber and and lumber products, such as cellulose and paper, are transacted by the All-Union Export-Import Organization (Eksportles). Similarly, all exports and imports of oil and oil products are carried out by Soiuznefteksport. A list of the twenty-eight combines now in existence and a partial list of the commodities and activities over which they have jurisdiction is given in the accompanying

\section{Rights of the Combine}

7. For the realization of the functions enumerated in paragraph 6 of the present charter, the All-Union Combine "Sudoimport" is given the right, in accordance with the corresponding laws, to:

a) perform all kinds of transactions, contracts, and other juridical acts, credit, commercial paper and banking transactions with institutions, enterprises, societies, associations and individual persons, both in the U.S.S.R. and abroad, sue and be sued, in courts and arbitral tribunals;

b) construct, establish, and let or take on lease enterprises subsidiary to its activitics both in the U.S.S.R. and abroad;

c) institute, in accordance with prevailing legislation, branches, offices, representatives and agencics both in the U.S.S.R. and abroad, as well as participate in all kinds of combines, societics, associations and organizations which correspond to the tasks of the Combine;

d) acquire, alienate, and let or take on lease any kind of movable or immovable property.

\section{Capital}

8. The chartered capital of the All-Union Combine "Sudoimport" is established at the sum of five million rubles.

\section{Administration of the Combine}

9. The administration of the All-Union Combine "Sudoimport" is carried out by the President of the Combine and his Deputies, in the order established by law.

The division of labor between the President and his Deputies is established by the President of the Combine.

10. The President of the Combine administers all the affairs and property of the Combine, performs and concludes, in the name of the Combine, all kinds of contracts, transactions and other juridical acts, and in the affairs of the Combine deals directly with all institutions, enterprises, and persons.

I1. All contracts and transactions in foreign trade concluded in Moscow by the All-Union Combine "Sudoimport" must be signed by two persons, of whom one must be the President of the Combine or his Deputy, and the other, a person authorized to sign foreign trade transactions by a power of attorney signed by the President of the Combine. Bills of exchange and other monetary obligations in foreign trade issued by the Combine in Moscow must bear the signatures of the President or his Deputy and the Treasurer of the Combine.

All foreign trade contracts, transactions and acts performed for acquiring or leasing of immovable property, as well as the issuance of bills of exchange and other monetary obligations, outside Moscow, both within the territory of the USSR and abroad, must be signed by two persons who have received, under powers of attorney signed by the President of the Combine, the right of first and second signing.

\section{Accounting and Distribution of Profits}

12. The fiscal year of the All-Union Combine "Sudoimport" runs from I January to 31 December of each calendar year.

13. Accounts and balance sheets of the All-Union Combine "Sudoimport" are drawn up and issued in the procedure established by the laws and regulations prevailing in the U.S.S.R.

14. The procedure for distribution of the net profit of the All-Union Combine "Sudoimport" is determined by the laws and regulations prevailing in the U.S.S.R.

\section{Liquidation}

15. The procedure for liquidation of the All-Union Combine "Sudoimport" is determined by the laws and regulations prevailing in the U.S.S.R. 
footnote. ${ }^{17}$ Apart from the foreign trade combines, a very few other state organs are specially empowered to carry on foreign trade within strict limits of authority. ${ }^{18}$

Despite its legal autonomy, the foreign trade combine is also part of the Soviet state monopoly of foreign trade. The formation of the combine is decreed by the Council of Ministers of the Soviet Union. Its charter is issued by the Ministry of Foreign Trade. Further, although mention of this fact is omitted from the charter, the Minister of Foreign Trade names both the president and vice-president of the combine, and they are subordinate to him administratively and subject to discipline by him. The Ministry of Foreign Trade may also dissolve a foreign trade combine,

17 The following is adapted from P.A. Cherviakov, Organizatsila I Tekhnika, Vneshnei Torgovil SSSR [Organization and Technique of Foreign Trade of the U.S.S.R.] $4 \mathrm{I}-43$ (1958).

Combines which only export: (I) Mashinoeksport: power-generating, electrical, mining, hoisting, metallurgical, chemical and food-processing equipment, and equipment for light industry; (2) Avtoeksport: automobiles, tractors, agricultural machinery, and control and measuring instruments.

Combines which only import: (3) Tekhnopromimport: equipment for chemical, construction, food, pulp, light, resin, and polygraphic industries, automobiles, tractors, agricultural machinery, telegraphic, television, and radio equipment, control and measuring instruments, and laboratory equipment.

Combines which both export and import: (4) Stankoimport: machine tools, metal forging equipment, instruments, ball-bearings, measuring tools, hard alloys, abrasives, film equipment, and optical apparatus; (5) Sudoimport: ships, their repair and re-equipment; (6) Promsyr'eimport: ferrous metals, railroad materials, ferrous alloys, high quality steels, pipes, and hardware; (7) Raznoimport: light metals, rolled light metals, rubber, and synthetic rubber products; (8) Eksportles: timber materials in finished and unfinished form, cellulose, paper, and paper goods; (9) Soiuzpromeksport: products of mining and fuel industries and fertilizers; (ro) Soiuzkhimeksport: chemical and medicinal goods and raw materials; ( 1 ) Soiuzncfteksport: oil and oil products; (12) Soiuzpushnina: fur peits and their products, bristles, horsehair, and carpets; (I4) Eksportlen: cotton, wool, flax, fabrics, thread and similar products; (I3) Eksportkhleb: grain, legume and oil cultures, oil cakes, seeds, and bran; (15) Prodintorg: food products other than those within the nomenclature of Eksportkhleb and animals; (I6) Raznoeksport: tobacco and tobacco products, hides, animal waste, leather products, and building materials; (I7) Mezhdunarodnaia kniga: books, periodicals, music, reproductions, stamps, articles for mechanical reproduction of music, and articles for fine arts; (I8) Soveksportfil'm: moving-picture films; (rg) Vostokintorg: various goods in trade with the Mongolian People's Republic, the Sinkiang-Uigurski autonomous region of the Chinese People's Republic, Afghanistan, and Iran; (20) Mashinoimport: imports of power equipment and electrical and petroleum hoisting equipment, and imports and exports of railroad rolling stock.

Combines engaged in transport: (2I) Sovfrakht: freighting of Soviet and foreign cargo, expediting, transfer of cargoes, and transit operations; (22) Avtovneshtransport: transfer by automobile and river transport of export and import cargoes between the U.S.S.R. and the Chinese People's Republic, Mongolian People's Republic, Afghanistan, and Iran.

Combines engaged in publishing and tourist operations: (23) Vneshtorgizdat: publication of books, brochures, journals, bulletins, and prospectuses on questions of foreign trade, and catalogue and advertising materials; (24) Intourist (joint stock company): organization of travel and service of forcign tourists in the U.S.S.R. and of Soviet tourists abroad.

In addition, the supply to foreign countries of complete enterprises and the rendering of technical aid, as well as the conduct of estimating and designing work, are carried on by (25) Tekhnoeksport, (26) Tekhnopromeksport, (27) Tiazhpromeksport, and (28) Prommasheksport-each dealing in different types of industry.

${ }^{18}$ Soveksportfil'm, which exports and imports moving pictures, cinematographic equipment, and related products, is subordinate to the Ministry of Culture of the U.S.S.R. and is not, technically speaking, an export-import combine. Skotoimport, which imports cattle for slaughter from countries of the East, is subordinate to the Ministry of Food Products. The Academy of Sciences has the right to purchase books and other scientific materials abroad. In addition, in connection with the Soviet program of technical assistance, some economic ministries and their chief administrations have been given the right to appear as parties to forcign trade contracts together with the foreign trade combine Tekhnoeksport, the cconomic ministry or chief administration being responsible for the production aspects of the contract and Tekhnoeksport being responsible for the commercial aspects. Pozdniakov, supra note 3, at I4-I5. 
upon authorization of the Council of Ministers. ${ }^{10}$ It may transfer basic capital from one to another; moreover, the annual net profit of the combine is turned over to the state as state income. ${ }^{20}$

Certain major obstructions to normal commercial intercourse are removed by the conferring of legal autonomy upon the foreign trade combine. Thus, the combine is not immune from process or from liability under Soviet law, and it does not claim immunity under the laws of other countries, at least in suits arising out of commercial transactions. ${ }^{21}$ Moreover, it accepts the traditional institutional framework of commercial custom and commercial law which is the common heritage of exporters and importers, bankers, shipowners, marine insurance underwriters, and other persons engaged in private trade throughout the world; the Soviet law and practice regarding c.i.f., f.o.b., f.a.s., and similar types of international trade contracts, letters of credit, and other financing devices, ocean bills of lading, marine insurance policies, and, in general, the entire range of commercial techniques of international trade does not differ in nature from that of Germany, France, Italy, England, the United States, and other countries which have inherited the law merchant. ${ }^{22}$

On the other hand, the fact that the Soviet foreign trade combine is part of the state monopoly of foreign trade introduces some legal complications into commercial relationships with private traders. One such complication arises when the Ministry of Foreign Trade refuses to issue an export license to a foreign trade combine. In a recent case before the Foreign Trade Arbitration Commission in Moscow, it was argued-unsuccessfully-by the non-Soviet party that the connection is so close between the foreign trade combine which made the original export contract and the Ministry of Foreign Trade which subsequently refused to grant license that the refusal to perform the contract cannot be excused on the ground of force majettre or supervening impossibility. ${ }^{23}$

Another complication arising from the fact that the foreign trade combines are state organizations is connected with the severe rules of Soviet law regarding ultra vires transactions-rules which are designed to prevent officials of state organizations from acting in a manner which is contrary to the interests of the state. Thus, article thirty of the R.S.F.S.R. Civil Code provides: "A legal transaction made for a purpose contrary to law, or in fraud of law, as well as a transaction directed to the obvious

${ }^{10} \mathrm{Cf}$. Genkin, supra note 15 , at $6 \mathrm{r}-62$. Dissolution or reorganization is regulated by a decree of the Central Executive Committee and the Council of People's Commissars of the U.S.S.R. of March 2\%, I936, Sobranie ZakoNov SSSR [COLIECTION OF LAWS OF THE U.S.S.R.] no. I8, art. I5I (I936).

${ }^{20}$ Genkin, supra note 15 , at 70 .

${ }^{21} \mathrm{Cf}$. charter of Sudoimport, supra note $16, \S 7(\mathrm{a})$. The waiver of immunity in the charter of the combine may be revocable under the doctrine of absolute immunity of some countries. In a $x 948$ libel of the Soviet vessel Rossia by an injured passenger, immunity was claimed and granted, but the ship was owned by the Soviet Ministry of Marine Fleet rather than by an independent combine. Lorina v. The Rossia, File No. 18767 (E.D.N.Y. 1948) (complaint dismissed without opinion).

${ }^{22}$ Much of this transnational body of legal concepts and institutions is accepted in tracle among the Communist countries themselves. See Berman, Unification of Contract Clauses in Trade between MemberCountries of the Council for Mutual Economic Aid, 7 INT'2 \& Comp. L. Q. 659, 664 (1958).

${ }^{23}$ See infra note 34 . 
prejudice of the State, shall be invalid." Article 147 provides: "In the event that a contract is invalid as illegal or directed to the obvious prejudice of the State (Article 30), none of the parties shall have the right to claim from the other restitution of that which the other party has performed under the contract. Unjust enrichment shall be collected for the benefit of the State (Article 402)." In commenting on the applicability of these provisions to a foreign trade contract which is ultra vires the Soviet foreign trade combine that concluded it, Professor D. M. Genkin, a leading Soviet authority, states: "However, judicial and arbitrational practice in those instances when there is not a malicious violation of the plan permits the application of consequences not under Article ${ }_{447}$ but under Article ${ }_{5} \mathrm{I}$ of the Civil Code of the RSFSR, i.e., permits bilateral return (restitution) of all that has been received under the ultra vires transaction."24

Article I5I provides: "Where a contract is declared invalid owing to violation of the form required by law (Article 29) or owing to mistake of one of the parties (Article 32), each of the parties must restore to the other all that which he received under the contract. . . ." In addition, it provides that compensation for damage to property shall be paid by the party liable for the circumstance which caused the mistake, and that compensation in damages as for breach of contract shall be paid if the mistake was caused by gross negligence.

The statement that in cases involving foreign trade contracts, Soviet courts and arbitration tribunals should apply article $15 \mathrm{I}$ instead of article 147 where the invalidity is not due to a malicious violation of plan indicates an awareness on the part of Soviet jurists of the difficulty which would be created if the severe policy of Soviet law concerning illegal contracts were applied to foreign trade contracts. At the same time, it is not clear how article I5I could be applied where the form of the contract was proper and there was no mistake of fact, and yet the plan was violated without malice-as where a foreign trade combine agrees to export an article which it knows it is not authorized to export, believing, nevertheless, that it is acting in the best interests of the Soviet state. Professor Genkin argues that the application of either article 147 or article I5I in such a situation would be "completely unacceptable," but he cites no authority for this view. ${ }^{25}$

"It would be incorrect to consider," he adds, "that the conclusion and execution by foreign trade combines of ultra vires transactions with a foreign trade partner should not incur any consequences whatever. The persons who concluded such a transaction on the side of the Soviet foreign trade combine, and who executed it, should be brought to disciplinary responsibility, and in proper instances also to criminal responsibility, for violation of the charter of the combine."26

In this connection, it may be mentioned that under article 59(II) of the R.S.F.S.R. Criminal Code and corresponding articles of the criminal codes of the other constituent republics of the Soviet Union, violation of the statute on the state monopoly

${ }^{24}$ Genkin, supra note 15 , at 67 .

20 Ibid.

${ }^{25} I d$. at 68 . 
of foreign trade is punishable as an "especially dangerous crime against the administrative order" by deprivation of liberty from three to ten years, with total or partial confiscation of property. "A particular instance of the violation of the monopoly of foreign trade," states one Soviet writer, "is the conclusion on the territory of the U.S.S.R. of trade transactions with foreign organizations and firms which may carry on activity on the territory of the U.S.S.R. only on condition they receive special permission, and such permission does not exist, and also the assumption of the authority of an agent for the purpose of performing transactions for such organizations and persons."27

It is not intended by the above discussion to suggest that the problem of ultra vires transactions is of pressing importance as an immediate obstacle to trade between the Soviet Union and foreign countries. The problem, nevertheless, sheds light on the general question of the extent to which rules designed primarily to meet the domestic needs of an economy operated and administered chiefly by state agencies are applicable to dealings with foreign firms. At the same time, the severe sanctions imposed on Soviet officials for a violation of the monopoly of foreign trade have a practical bearing upon business relationships between foreign trade officials and foreign firms. ${ }^{28}$

\section{All-Union Chamber of Commerce}

The establishment of the All-Union Chamber of Commerce provides another illustration of the attempt of the Soviet regime in the field of foreign trade to adapt the state monopoly to the requirements of an international order. In many ways, this organization resembles chambers of commerce established by private traders in market economies. It is a juridical person, with the right to acquire, alienate, and lease movable and immovable property; to enter into transactions within the limits set by its charter; and to sue and be sued in court. ${ }^{20}$ Its functions include those of establishing links with economic organizations abroad, especially chambers of commerce, export institutes, and trade exchanges; participating in the international congresses of chambers of commerce; reception of foreign trade and industrial delegations, and sending of similar delegations abroad; organization of foreign and domestic trade and industry fairs both within the Soviet Union and abroad; handling of Soviet patent and trademark applications and claims abroad, and representation of foreigners in such applications and claims in the Soviet Union; issuance of certificates of origin of goods exported from the Soviet Union; ${ }^{30}$ issuance of certificates of

${ }^{27}$ Pozdniakov, supra note 3 , at 18 .

${ }^{28}$ Sanctions for violation of the laws on state secrets and on counterrevolutionary crimes are discussed infra note 52 .

${ }^{28}$ This and the following information is drawn in part from Pozdniakov, supra note 3, at 33 et seq., and in part from conversations with officers of the Chamber. The charter of the All-Union Chamber of Commerce issued by the Council of People's Commissars of the U.S.S.R., August 2, I943, which is quoted by Pozdniakov and other Soviet writers, is not available.

${ }^{30}$ Certificates of origin of goods imported into the U.S.S.R. are issued by trade delegations and trade agencies of the U.S.S.R. abroad or by consular institutions of the U.S.S.R. where such trade delegations or agencies do not exist. 
quality after expert examination; and arbitration of trade and maritime disputes through two arbitral tribunals, the Foreign Trade Arbitration Commission and the Maritime Arbitration Commission.

The charter of the All-Union Chamber of Commerce, as quoted by Soviet writers, specifically declares it to be a "social" organization, and hence it is not, under Soviet law, a "state" organization. Social organizations are distinguished from state organizations under Soviet law by the fact that membership in them is voluntary and the members participate to a relatively high degree in the administration of their affairs. $^{31}$ In addition, a social organization, as contrasted with a state organization, is not legally subordinate to any particular organ of the government. Nevertheless, article one of the charter of the All-Union Chamber of Commerce is quoted as stating that the Ministry of Foreign Trade "exercises general supervision" over its activity. ${ }^{32}$

The membership of the All-Union Chamber of Commerce includes, however, many organizations other than those which participate directly in foreign trade. There are reported to be several hundred or more members, drawn from various branches of industry and commerce, and it is emphasized by Soviet officials that the functions of the Chamber include participation in activities connected with domestic trade.

The fact that the All-Union Chamber of Commerce-at least to the extent that it participates in activities connected with foreign trade-helps to exercise the state foreign trade monopoly, and that its members are often officials of state organizations, raises the question whether the arbitration commissions which are attached to it, and whose panels are appointed by its presidium, are sufficiently independent of the Soviet foreign trade combines to be considered impartial in cases of disputes between them and foreign firms. There is much evidence that the Foreign Trade Arbitration Commission has striven to achieve a reputation for impartiality (without which, indeed, it would be difficult to secure consent of foreign parties to its jurisdiction). It has shown a thorough familiarity with the commercial law and commercial custom of many countries; its fifteen-member panel of arbitrators are, for the most part, prominent professors of law or economics who are experts in internätional trade; its procedure is fair; it gives reasoned opinions in connection with its awards; and it has decided many cases in favor of the non-Soviet party. ${ }^{33}$ Althoụgh

${ }^{31}$ Cf. 2 P. I. KudRinvtsev (Ed.), Iuridicheskir SLovar' [Legal Encyclopedia] 23 (1956). Other social organizations are: the Communist Party, the trade unions, the civil defense societies, scientific and technical organizations, sports societies, and others.

${ }^{32}$ R.S.F.S.R. CrviL CoDE art. I8 (r956) (U.S.S.R.) is applicable to social organizations. KudRzAvTsEv (ED.), op. cit supra note 31 . Art. I 8 states: "The existence of a juridical person may be terminated by the proper organ of government authority if the juridical person deviates from the purpose defined by the charter or contract or if the activities of its organs (general meeting, management) deviate in a direction contrary to the interests of the state." In the light of the provision of the charter quoted in the text, it is very likely that the Ministry of Foreign Trade would be "the proper organ of government authority" should a question of terminating the All-Union Chamber of Commerce under art. 18 ever arise.

${ }^{33}$ This conclusion is based, in part, upon a study of original reports of more than twenty awards on file in the archives of the Commission, which the writer conducted in Moscow in May 1957; in part, upon interviews with Western businessmen who have had cases in the Commission; and in part, upon numerous 
its recent decision against an Israeli oil import corporation caused considerable adverse comment in the Western press, that case had peculiar political implications which render it atypical. ${ }^{34}$ Nor were the legal issues as simple as many critics of the award have supposed. ${ }^{35}$

It has been suggested, however, that "the tribunals of the Communist Chambers of Commerce are, in fact, administrative agencies of their respective governments in the guise of arbitration, and not arbitration tribunals at all."36 In support of this view, it is stated that both the Soviet Chamber of Commerce and its Foreign Trade Arbitration Commission are "public institutions created by the state, with responsibilities of a purely public nature and with secretariats and arbitration panels unavoidably composed of civil servants."37 Such a position would deny the reality of the

reports of cases in Soviet books and periodicals and in some reports in non-Soviet literature. A detailed description of a proceeding in the Commission is given by a West German attorney who represented a Hamburg company in a suit against the timber export combine Eksportles in 1956; see Shaer, Bericht ïber die Durchführung eines Schiedsverfahrens vor der Aussenhandels-Arbitragekommission bei der Handelskammer der U.d.S.S.R. in Moskau," 3 RECHT DER INTERnationalen WIRTsCHAFT 75, 76 (1956). The work of the Commission is analyzed in Dmitril F. Ramzaitsev, VNeshnetorgovyi Arbitrazh I SSSR [ForeIgN TRADE ARbitration IN THE U.S.S.R.] (1952) and (1957), and reports of its activities are occasionally given in the monthly journal of the Ministry of Foreign Trade, Vneshniaia Torgovlia. Cf. Hazard, State Trading and Arbitration, in Martin Domer (Ed.), International Trade Arbitration: A Road to WorrdWide Cooperation 93 (1958). Decisions of the Foreign Trade and Maritime Arbitration Commissions are discussed in Pisar, Soviet Conflct of Laws in International Commercial Transactions, 70 Harv. L. REv. 593 (I957).

si The case was that of Jordan Investment Ltd. v. Soiuznefteksport, involving a claim of over two million dollars arising from the defendant's failure to deliver oil as provided by contract; the defense was denial to the defendant of an export license by the Ministry of Foreign Trade. The decision is reported in N.Y. Times, June 20, 1958, p. I, col. I; see also id., Dec. 5, 1957, p. 21, col. 3. Cf. Observer (London), June 26, 1958; Manchester Guardian, June 27, 1958. More or less indiscriminate indignation over the decision was expressed in many quarters. Cf. Notes on Israeli-Soviet Oil Arbitration, I3 ARB. J. 159 (r959).

The political background of the case consisted in the invasion of Egypt by Israel in November 1956, which the Soviet Government considered an act of aggression; in the fact that the Israeli oil import corporation is itself controlled by the Israeli Government; and in the fact that a large amount of pressure concerning the case was brought to bear on the Soviet Government by traders from many countries, which ultimately may have produced the opposite effect from that which was intended.

${ }^{35}$ The Israeli plaintiff argued that the connection between the Soviet Ministry of Foreign Trade and the defendant oil export combine is so close that the Ministry's refusal to grant export licenses could not be treated as creating a supervening impossibility under the force majeure clause of the contract. This attempt to pierce the combine's corporate veil was bound to fail, however, since such legal autonomy is, as indicated above, a basic principle of the entire Soviet system of foreign trade; to reject it would be to require the Soviet state to conduct all its foreign trade in its own name-a solution which would probably create more difficulties for non-Soviet traders than it would solve. Having chosen to contract with the Soviet combine in Moscow, the plaintiff was in no position to deny its independence under Sovict law. On the other hand, the tribunal's holding that the Soviet exporter was not liable for damages caused by its government's denial of the license, there being no provision of the contract expressly covering this contingency, is probably contrary to general international commercial understanding, although judicial decisions on this point are not uniform throughout the world. It should be noted, however, that the Soviet Foreign Trade Arbitration Commission has in at least one other case involving the denial of an export license taken a very broad view of force majeure-and to the disadvantage of the Soviet import combine. Moreover, the contract in the Israeli case provided that there should be no liability for nonperformance "due to any other cause whatever beyond the control of the defaulting party" -language which is broader than the conventional phraseology of force majettre.

${ }^{30}$ Pisar, Treatment of Communist Foreign Trade Arbitration in Western Courts, in Domke (ED.), op: cit. supra note 33, at ror, 106.

.. 2iT Ibid. 
Soviet distinction between "social" and "state" organizations-a denial which gains some force by virtue of the above-quoted provision of the charter of the All-Union Chamber of Commerce (a "social" organization) that it is "under the supervision" of the Ministry of Foreign Trade (a "state" organization); it would also deny the reality of the distinction between a university professor and a civil servant.

More telling, perhaps, is the fact that under article 124 of the Soviet Constitution, the members of the Communist Party are stated to be the "leading core of all organizations, both social and state"; given strict Party control over all aspects of social and economic life, it may easily be supposed that Soviet arbitrators are directly responsible to Soviet national interests as interpreted by the Party leadership.

Such an analysis must somehow explain the fact that the decisions of the Foreign Trade Arbitration Commission in the past twenty-five years give no indication of any lack of independence-at least if the Israeli case is left out of consideration. If it is assumed that the arbitrators are under instructions from the Ministry of Foreign Trade (or the Communist Party), it must also be assumed that those instructions are: Behave as though you were impartial! ${ }^{38}$ One might also suppose, however, that no such instructions are needed and that the arbitrators, as well as the Ministry of Foreign Trade, understand that the success of the tribunal, in the long run, depends on its international reputation for objectivity and fairness. In addition, Western concepts of the monolithic communist state may be oversimplified: Soviet domestic state-trading and industrial enterprises have had a long experience of impartial adjudication of disputes arising out of their contracts with each other, and it may simply be taken for granted by both officials and arbitrators that foreign trade combines are subject to similar controls, although the opposing parties are foreigners. ${ }^{39}$

If one assumes that the Soviet arbitrators are impartial, in fact, there remains the

${ }^{38}$ Cf. id. at 107: "If [the Soviet arbitrators] are at all influenced by the State, it is more likely than not that their attitude takes the form of what may be called 'premeditated impartiality." " In and of itself, of course, premeditated impartiality is the best kind. The vice of an "instructed" impartiality is in the possibility that the instructions might be withdrawn in a particular case.

${ }^{30}$ Interestingly enough, the term Arbitrazh is used for both the Foreign Trade Arbitration Commission (Vneshtorgarbitrazh) and for the state agencies which decide contract disputes between state enterprises of different ministries or branches of the economy (Gosarbitrazh). (There are several hundred thousand such disputes decided annually.) Despite the resemblance of the term to the Western word "arbitration," it does not have that connotation in Soviet domestic adjudication. Indeed, there is another term in Russian for an arbitration tribunal, treteiskii sud, and a statute of 1924 recognizes the validity of awards of such tribunals. The 1956 legal encyclopedia concludes its discussion of that statute by stating: "In the U.S.S.R. citizens do not use arbitration tribunals [treteiskii sud], since they resort with full confidence to the people's courts. At the All-Union Chamber of Commerce there exist as permanently functioning arbitration tribunals [treteiskii sud] the Foreign Trade Arbitration [arbitrazhnaia] Commission and the Maritime Arbitration [arbitrazhnaia] Commission." KuDRIAvTsEv (ED.), op. cit. supra note 31, at 517. On Gosarbitrazh, see generally Harold J. Berman, Justice in Russin 63-66 (I950); I3 decisions of Gosarbitrazh are reported and discussed in Haroud J. Berman \& Boris A. Konstantinovsky, Soviet Law in Action: The Recollected Cases of a Soviet Lawyer $33 \mathrm{et} \mathrm{seq.} \mathrm{(1953).} \mathrm{The} \mathrm{fact} \mathrm{that} \mathrm{legality} \mathrm{in}$ the domestic economic sphere is accepted and believed in by the Soviet leadership, and is given institutional expression in a body of law which is objectively applied, has an important bearing upon the question of the nature and quality of Soviet foreign trade adjudication. Cf. Berman, Soviet Justice and Soviet Tyranny, 55 Colum. L. Rev. 795 (1955). 
question whether their links with the Soviet export-import combines are not so close as to cast doubt on their legal capacity for impartiality. So long as these three conditions co-exist: (a) that they are appointed by the All-Union Chamber of Commerce, (b) that the All-Union Chamber of Commerce is under the supervision of the Ministry of Foreign Trade, and (c) that the Ministry of Foreign Trade appoints the heads of the export-import combines-so long will their independence be subject to potential abuse.

\section{B. Integrated National Economic Planning As the Basis of Soviet Foreign Trade}

Soviet writers contrast the planned character of Soviet foreign trade with the "spontaneous, plan-less character" of the foreign trade of capitalist countries, "whose economy develops spontaneously." In the Soviet Union, "foreign trade is supposed to be subordinated to the requirements of the national economic plan. Plans for foreign trade are supposed to proceed from the general tasks of the national economic plan...." These tasks are: "a) guaranteeing the independence of the development of the national economy, b) the victory ... of the socialist system of economy and the gradual transition to communism, c) rejection of disproportions in the national economy and the creation of necessary reserves for the struggle against such disproportions." 40

The economic tasks of Soviet planning are reflected in the import and export policies of the Ministry of Foreign Trade. Soviet economic independence, rapid industrialization ("transition to communism"), and the building up of reserves against future unfavorable economic contingencies, are goals which are reached, in the first instance, by economizing exports. Exporting is viewed as necessary in order to earn the foreign exchange needed for imports, but not as something which is desirable in and of itself, for its own sake. If there were no need for imports, there would be no economic pressure to export. Secondly, the economic goals of Soviet planning limit imports in general to those goods which either cannot be manufactured or produced at home at all, or which it would be very difficult or very costly to manufacture at home. The mere fact that it is more costly (but not much more costly) for the Soviet Union to manufacture cosmetics, for example, than to import them from abroad would not in itself induce the Soviet planners and administrators to authorize their importation, for they do not operate on a theory of comparative costs, except in a very rough sense. Indeed, they have no precise way of estimating comparative costs, in view of the fact that the ruble is a purely internal currency, and even internally there is not a free market. Even if they could measure comparative costs precisely, they would not base their planning upon them, for one of their goals is to free Soviet economic development from dependence upon foreign markets, rather than to integrate their economy with foreign economies.

It is, of course, true that in economies in which foreign trade develops more

${ }^{10}$ SMirnov \& Liubimov (Eds.), op. cit. supra note 9, at 9, I7, 18. 
spontaneously and without planning of the Soviet type, there are, in many cases, governmental controls designed to restrict exports of goods needed at home and to give priority to imports of industrial goods and other goods not easily manufactured at home. The striking difference is that in a capitalist economy, there is, by definition, a large class of people, private businessmen, whose individual interests are not identical with those of the state and who exert a pressure toward free multilateral trade. Individual exporters and importers impose limits on the extent to which the state can control foreign trade for national ends, whether economic or political. The individual exporter, for example, views exports-even of scarce items-as in themselves desirable. He makes a profit from them. Similarly, the individual consumer may prefer to import from abroad goods which it would be only slightly more expensive to buy at home. A government in a capitalist economy must reckon with such individual private interests; and, indeed, it is often itself sympathetic with them. In the Soviet Union, such pressure for foreign trade is exerted by two dozen export-import combines and by some ministries and some economic organizations, all of which are headed by state officials who are supposed to view the interests of their own organizations in the light of the total interests of the country.

\section{Techniques of foreign trade planning}

Soviet literature reveals very little of the concrete details of foreign trade planning, and Soviet foreign trade officials are reluctant to reveal to foreigners the actual methods by which decisions are reached as to what to import and what to export. ${ }^{41}$ It is not clear to what extent the Ministry of Foreign Trade plays an independent part in the formulation of the annual export and import plans, ${ }^{42}$ to what extent the various economic ministries can influence the decision to import or export particular products, to what extent the Ministry of Foreign Affairs can determine patterns of trade, to what extent the State Bank influences foreign trade planning, and so on.

The accounts of Soviet foreign trade planning which are available to foreign scholars do, however, make clear the high degree to which the immediate producing and consuming enterprises, and even their chief administrations and ministries, are insulated from direct contact with foreign markets. In importing, the foreign trade combine, on the basis of its import plan, requests from the appropriate ministry or chief administration specifications of the particular products which the organization is authorized by the plan to purchase abroad. On the basis of such specifications, the combine goes onto the foreign market-subject to limitations imposed by Soviet

${ }^{11}$ In a personal interview with First Deputy Minister of Foreign Trade S.A. Borisov in May I957, the writer stated that American businessmen and scholars are interested in obtaining more information on how Soviet foreign trade is planned. Mr. Borisov replied: "How we plan our foreign trade is our own business, and we are not going to tell you or anyone else."

"A Soviet book on foreign trade states: "In 1953 , in order to raise the responsibility of ministers of the U.S.S.R. for the tasks assigned to them, and also taking into account the importance of securing timely decisions of cconomic questions connected with the fulfillment of the taks impmed nn ministries, the rights of ministers of the U.S.S.R. were significantly extended," However, not a word is said as to what new rights they were given. Pozdniakov, supra note 3 , at 21 . 
bilateral trade agreements ${ }^{43}$-to procure the goods. Armed with an import permit from the Ministry of Foreign Trade, the combine makes a contract with the foreign supplier; as a rule, it only then enters into a contract with the domestic customer ${ }^{44}$ and, indeed, if it chooses not to enter into such a contract, the domestic customer is, nevertheless, bound to buy the goods by the import permit issued by the Ministry of Foreign Trade. The price which the domestic customer pays for the goods is the price of similar goods in the internal market; or, if there are no similar goods, a price fixed by the Ministry of Foreign Trade, ${ }^{45}$ plus a customs duty. The amount of the customs duty is apparently supposed to be equivalent to transportation expenses and the organization's commission.

In exporting, the obligation of a producer organization to take the necessary preliminary steps to produce particular goods for export is created by the annual national economic plan and, more particularly, by the allocation of export contingents by the Council of Ministers of the Soviet Union. On the basis of a corresponding export plan, the foreign trade combine presents to the appropriate ministry or chief administration an order (zakaz-nariad) which obligates the ministry or chief administration to deliver the goods. The ministry, or chief administration, issues a corresponding $z a k a z$-nariad (or transfers the original zakaz-nariad) to one of its subordinate producing enterprises. The zakaz-nariad, which contains the number and date of an export permit issued by the Ministry of Foreign Trade, creates a legal obligation to deliver on the part of the ministry or chief administration; again, no contract is required..$^{46}$

Either before or after it issues orders to supplier organizations, the foreign trade

13 See infra 499-500.

44 "If the foreign supplier does not agree to the conditions based on the specifications [presented by the domestic producer] the combine turns to its principal with the suggestion to change the technical conditions if possible." Finogenov, Pravovye Voprosy Importnykh Operatsii [Legal Questions of Import Operations], in GeNkIN (ED.), op. cit. supra note 3, at I10, I12-13.

*5 If the imported goods are sold to the public, the Ministry of Foreign Trade may apparently set any price it wishes; if they are machines, equipment, or means of transportation, the price is based on the cost of the goods plus a supplementary amount measured according to rules adopted by the Ministry of Foreign Trade. Id. at r24. It is not indicated on what basis the rules for the supplementary amount are framed or at what rate of exchange the foreign price is translated into rubles.

${ }^{10}$ In Soviet domestic trade, direct procurement or allocation of goods without contract is confined to relatively few kinds of transactions. One Soviet writer states: "The practice of non-contractual deliveries lowers the responsibility of the suppliers, often leads to shipment of goods which the consumer does not need, to non-rational transshipments, to the growth of abnormal deficiencies, to overstocking. In particular, the practice of non-contractual deliveries of ferrous metals, coal, and oil products has [in recent years] been abolished.

"At the present time the creation of obligations by non-contractual means is permitted by law as an exception from the general rule only in particular instances.

"Thus, in particular, to the number of obligations arising by non-contractual means belong obligations for delivery of goods for export. . . .

“. . This [elimination of contracts between the domestic suppliers and the foreign trade combines in October 1940] guaranteed to the all-union foreign trade combine the possibility of morc operational, resourceful, flexible work in connection with their appearance on foreign markets and with fulfillment of their contractual obligations with foreign trading partners." Zatsepin, Pravovye Voprosy Postauki Tovarov ne Esksport [Legal Questions of Supply of Goods for Export], in GENKIN (ED.), op. cit. supra note 3 , at $89,9 \mathrm{I}-92$. 
combine goes out onto foreign markets-again, as limited by intergovernmental trade agreements-and makes contracts with foreign purchasers. It pays the supplier after delivery of the goods, at the established domestic wholesale price. ${ }^{47}$ It receives a commission from the proceeds of the sale abroad and transfers the balance (after subtracting the price paid to the domestic supplier) to the state treasury. It is not stated in Soviet literature, so far as this writer can discover, how the combine's commission is translated from foreign currency into rubles.

\section{Problems arising from the planned character of Soviet foreign trade}

The underlying problem arising from the fact that Soviet foreign trade is integrally (or "globally") planned and that of its Western trading partners is to a considerable extent free, or "spontaneous," is the lack of reciprocity which exists between the immediate trading partners. A commercial contract is an instrument whereby each of two parties gives up something to the other in the expectation of being better off himself as a result. The reciprocal exchange of sacrifices makes them both wealthier. But in the case of contracts between a capitalist trader and a Soviet foreign trade combine, the kinds of advantages achieved are apt to be quite different for each partner. The Soviet foreign trade combine considers itself better off only if the transaction conforms to the plan and, in that sense, is of benefit to the Soviet state; whereas the capitalist considers himself better off if he has made a profit, even though the state may have suffered a net economic or political or military loss.

It is the absence of reciprocity in this fundamental sense which gives rise to particular difficulties in the attempt to put trade between planned and market economies on the basis of commercial considerations only. ${ }^{48}$ Also, it is the lack of reciprocity in this sense which makes it seem desirable to some governments of market economies that trade between their countries and countries of planned economy be regulated-as the Soviet leaders prefer that it be regulated-by bilateral trade agreements, with programs of exchanges of particular goods in particular quantities over a period of years, so that the planned character of the foreign trade of planned economies may be taken advantage of by both sides and not merely by one. ${ }^{40}$

It is apparent that the planning, administration, and operation of a system of foreign trade such as the Soviet is made easier by such bilateral programmed trade agreements. On the basis of the export contingents listed in such agreements, the Council of Ministers of the Soviet Union can make an allocation of export con-

$\triangle 7$ Ibid.

4⿴囗十 The commercial-considerations formula is used in the General Agreement on Tariffs and Trade as a means of controlling state trading. See General Agreement on Tariffs and Trade, Mar. 10, 1955, art. I7, [1957] 8 U.S.T. \& O.I.A. I767, T.I.A.S. No. 3930 (effective Oct. 7, 1957).

"Over 30 such trade agreements between the Soviet Union and noncommunist countries and over 240 such agreements between all countries of the free world and of the Sino-Soviet bloc are listed in Mikesell \& BeHRMaN, op. cit. supra note I, app. table I, at I03. In addition, all the communist countries have such trade agreements with each other. 
tingents among the producing and consuming ministries, chief administrations, and subordinate producing enterprises. ${ }^{\mathbf{5 0}}$ Similarly, import planning can be geared into the bilateral programs of exchanges.

On the other hand, for private traders in market economies, the establishment of contingents by intergovernmental agreement is a limitation upon freedom of action which is necessarily discriminatory, although it protects the national interests of the parties to the agreement. The Soviet Government's agreement with the Yugloslav Government, for example, to import leather from Yugoslavia adversely affects American leather exporters who might otherwise be able to compete on the Soviet market. Thus, the Soviet system puts governments of market economies in a dilemma: they may leave their private traders to deal individually with the Soviet state-trading combines and thereby sacrifice reciprocity in the sense indicated above, or they may enter into intergovernmental agreements which ensure reciprocity on a national basis but which necessarily interfere with the competitive position of individual traders in their own and other countries. ${ }^{51}$

\section{The Significance of Communist Party Leadership for the Soviet System of Foreign Trade}

It would be entirely unrealistic to analyze the Soviet system of foreign trade only in terms of state administration and economic planning, and to ignore the fact that the administration and planning is under the control of the Communist Party of the Soviet Union, a party which operates on the basis of distinctive theories and policies. It is conceivable that a particular country could have a state monopoly of foreign trade, conducted on the basis of a national economic plan, and not be a country led by a Communist Party; but the fact that the Soviet Union is led by a Communist Party and the fact that there is an opposition of political ideas and interests between the Communist Party of the Soviet Union and the governments of some countries of market economy add a whole other dimension to the legal problems of trade between it and other countries.

In the preceding sections of this article, consideration has been given to certain problems of adjustment between the Soviet system of foreign trade and that of nonSoviet countries-problems which would exist even if those countries shared common political aims and interests. In the present section, consideration is given to problems of trade which exist solely or primarily because of the political tensions between countries of planned economy led by a Communist Party and countries of market economy led by parties which are not communist. Attention is here given to problems arising because of Soviet political aims and interests; the second part of this article will be devoted, in part, to problems arising because of American political aims and interests.

\footnotetext{
${ }^{50}$ Cf. Zatsepin, supra note 46 , at 92 et seq. The word "contingents" in the expression "allocation of export contingents" may be taken from the bilateral trade agreements in which the same word (in Russian, kontingenty) is used.

${ }^{51}$ See infra $524-25$.
} 
It is due in large part to the international political situation, and not only to the inherent nature of a state-administered and centrally planned system of foreign trade; that large amounts of significant economic data are kept secret by the. Soviet Government. In particular; the contents of Soviet foreign trade plans, and even the details of the planning process, are not available to businessmen of other countries; indeed, their divulgence by Soviet officials - is subject to the laws on state secrets and on counterrevolutionary crimes. ${ }^{52}$ It is, therefore, impossible for a foreign businessman to make the same kind of independent, informed estimate of market developments in the Soviet Union that he can make of market developments in noncommunist? countries.

Secondly, it is impossible for a foreign businessman to have confidence that even though the Soviet customer is satisfied, political factors will not cause a change in the plans.

Thirdly, it is difficult if not impossible for the non-Soviet businessman to make the same kind of friendly contacts with Soviet foreign trade officials that he can make with businessmen or government officials of noncommunist countries-contacts which can make negotiations much easier.

Fourthly, a foreign businessman cannot set up a branch or an office in the Soviet Union; and even if he could, he could not have free contact with Soviet producing and consumer enterprises..$^{52}$

Fifthly, a Western manufacturer who sells complicated machinery to the Soviet Union usually finds it impossible, or at least highly exceptional, to be able to."service

${ }^{63}$ Under legislation of $\mathrm{x947}$, disclosure of a state secret was punishable by .confinement in a corrective labor camp from 8 to 12 years. State secrets were defined to include "all kinds of measures in the sphere of foreign policy and foreign trade not contained in officially published data." Edict of June 9, ig47 on Responsibility for Disclosure of State Secrets, $\S x$; and Decree of June 8 , 1947 on the Establishment of a List of Information Constituting State Secrets, $\$$ 12, translated in Harold J. Berman \& Miroslay Keprep, Documents on Soviet Military Law aND ADMinistration 100, I02 (1955). In addition, under the notorious art. $5^{8}$ of the R.S.F.S.R. Criminal Code, it is a counterrevolutionary crime to diśclose riot only state secrets, but also "economic information not containing a specially protected state secret but which by direct prohibition of law or by regulation of the director of a department, institution or, enterprise is not allowed to be published." R.S.F.S.R. CRIMINal CODE art. 58(6) (I952) (U.S.S.R.); translated in id. at 97-98. Recently there have been some important changes in these laws. By a decree, of, the Council of Ministers of the Soviet Union of April 28, 1956, the list of information constituting state secrets June 8, 1947 was abolished and a new list substituted which is much narrower and more precise than the former list, but which does include, under "information" of an economic character," economic statistics of various kinds, unpublished discoveries and inventions having important scientific or economic significance, data on foreign exchange and precious metals, and "other data which may be added by the Council of Ministers of the USSR to the list of information comprising state secrets." See R.S.F.S.R. Criminal CODE I43-45 (1957) (U.S.S.R.). In December 1958, a Law on Criminal Responsibility for Crimes against the State was enacted to replace earlier laws on counterrevolutionary crimes. The text of the law was published in Pravda, Dec. 26, I958, p. 3; it is translated in Current Digest of the Soviet Press, March II, 1959, p. 4. Section 12 of the law makes punishable by deprivation of freedom from 2 to 5 years, or from 5 to 8 years if the act has grave consequences, the "disclosure of information constituting a state secret by a person who was entrusted with such information or who gained it in his official capacity or work, and given the absence of elements of treason or espionage."

E2a "Foreign firms which intend to conduct continuous trade activity on the territory of the USSR" . . [must] receive special permission from the Ministry of Foreign Trade. In practice such foreign' firms or their representatives on the territory of the USSR at the present time do not exist." Pozdniakov, supra note 3 , at 15 . 
the product" and conduct the kind of technical follow-up which is almost essential to good business relations in many fields.

Sixthly, great difficulties are put in the way of protection of foreign patents. ${ }^{\text {53 }}$

Finally, visa formalities and other difficulties of access to the Soviet Union often exist-despite substantial improvement of the situation in recent years.

All these obstacles, it is submitted, are in large part due to political factors, though they are also due, in part, to rigid conceptions of state monopoly and of national economic planning.

\section{x. The use of trade for political objectives}

The fact that all Soviet foreign trade is in the hands of state agencies makes it easy for such trade to be withheld from countries or firms which have acted in a manner which the Soviet Government considers to be hostile to its interests. Presumably Soviet export-import combines would not wish to enter into commercial relations with such countries or firms, at least without receiving prior assurance from the Ministry of Foreign Trade that they need not hesitate to do so. In enforcement of such self-restraint, a decree of the Council of People's Commissars of I927 adjures the People's Commissariat of Foreign and Domestic Trade (as it then was) to see to it that foreign trade operations of trade delegations and of appropriate economic organizations be conducted "as a rule" only with those countries with which the Soviet Union has normal diplomatic relations and in which the Soviet foreign trade apparatus is guaranteed the possibility of normal commercial activities. ${ }^{64}$ A further decree of r930 authorized the same People's Commissariat to take countermeasures against countries which restrict Soviet commercial activities, and in particular to cut off or reduce trade with such countries, boycott shipping of such countries, limit transit through the Soviet Union of goods to or from such countries, and cut off or reduce the use of ports, means of communication, and bases of such countries for transit or re-export of Soviet goods. ${ }^{55}$ In r936-39, all export combines and other economic organizations were forbidden to export Soviet goods-including goods which they were already under contract to export-to countries whose exchange controls or administrative regulations did not permit Soviet organizations to use money received for Soviet exports to pay obligations incurred in the past by such organzations or trade delegations. Indeed, the People's Commissariat of Foreign

ss There is an adequate machinery for registration of Soviet patents by foreign nationals, under a law of March 5, I94I, translated in 2 V. GsovskI, SovieT CrviL LAW 36I-84 (1948). However, Sovict state organizations are not subject to the rights of the patentee if the invention was in use by them prior to the issuance of the patent; thus, one difficulty is to determine in advance, prior to the disclosure of the patent, whether they were, in fact, using the invention. A second difficulty is that royalties are payable in rubles, which can be used only in the Soviet Union. A third difficulty is in securing detailed information regarding the use of the invention after the patent has been issued. A fourth difficulty is that in the event that the invention is of special importance to the Soviet economy, the Government may decree its forcible alienation or compulsory licensing and may set the amount of remuneration to be given to the inventor.

st Decree on Measures to Guarantee the Normal Course of Operations in Foreign Trade, Sobranis ZAKonov SSSR [CoLIECTION of LAwS of THE U.S.S.R.] no. 28, art. 294 (1927).

${ }^{65}$ Decree on Economic Relations with Countries Which Have Established Restrictions on Trade with the U.S.S.R. Id. no. 53, art. 557 (I930). 
Trade was authorized to prohibit export of goods, and also to stop goods already dispatched, to countries "whose legislation, administrative regulations, administrative and judicial practice or established exchange restrictions would create unfavorable conditions for the foreign trade of the USSR."50

"These decrees of the Soviet government, directed to the defense of the foreign trade of the USSR from discriminatory measures of imperialistic states, do not exhaust, however, all possibilities of the Ministry of Foreign Trade for protection of the economic interests of the Soviet state," a Soviet writer states. ${ }^{57}$

From the very fact of the presence in the Soviet Union of a state monopoly of foreign trade, whose realization is imposed on the Ministry of Foreign Trade, the conclusion must be drawn that it has the right to prohibit particular Soviet organizations to conclude transactions with individual firms which have an incorrect attitude [neloiialno otnosiashchimisia] to the Soviet Union and to Soviet organizations, and also to repeal previously issued permits for the performance of transactions with them, and that it has the right to dissolve transactions which bring clear economic or other damage to the Soviet state. Not so long ago, for example, "Sovfrakht" [the Soviet shipping combine] concluded a contract for the hire of a vessel (time charter) with a foreign firm. Under the contract the shipowner was obliged to provide a vessel for carriage of Soviet cargoes between various ports, with passage in particular to Chinese ports. At the time provided in the contract the firm grossly violated the contract and forbade its vessel to pass into ports of the Chinese People's Republic, relying on orders of its government based on the unlawful decision of the General Assembly of the U.N. In answer to this the Ministry of Foreign Trade forbade "Sovfrakht" to engage in further conduct of operations with the aforementioned steamship company.

In addition to taking retaliatory measures against businessmen of countries which restrict trade with the Soviet Union and against firms which it considers to have an "incorrect" attitude, the Soviet Government uses foreign trade as a positive aid to fulfillment of its foreign policy objectives. For this purpose, it has used large-scale loans, technical assistance, purchases of commodities which it does not need, cancellation of contracts and of agreements, and embargoes. ${ }^{58}$

${ }^{50}$ Pozdniakov, supra note 3 , at $16-17$.

or Ibid.

os The United States Department of State has reported that from I955 through 1958 , the communist bloc had signed agreements with 18 underdeveloped countries to provide approximately $\$ 1,600,000,000$ in economic aid and $\$ 800,000,000$ in military aid. N.Y. Times, March 22, 1959, p. I, col. 6 . In January 1958, the State Department estimated that the Soviet Union had in recent years extended credits to forcign countries in the amount of $\$ 1,900,000,000$, at interest rates of 2 to $2 \frac{1}{2} \%$. Id., Jan. 4,1958, p. 4 , col. 2; Jan. 5, 1958, p. 15, col. I. In December 1958, a Hungarian publication stated that the Soviet Union had extended credits amounting to $\$ 7,000,000,000$ to East European countries, at $2 \%$ interest. Id., Dec. 29, 1958, p. 4, col. 3. See generally Joseph S. Berdiner, Soviet Economic Aid (I958), MikeSELL \& BERRMAN, op. cit. supta note I.

Some specific examples of Soviet foreign trade transactions geared to Soviet political objectives are the following:

In September-October I951, when the foreign trade of Iran was almost at a standstill following the nationalization of the Anglo-Iranian oil company, the Soviet Union made large-scale barter agreements with Iran which enabled that country to obtain needed commodities which she could not procure in the West. N.Y. Times, Sept. 26, I951, p. 5, col. 3; id., Oct. 25, r951, p. ro, col. 6.

In 1955, when Burma found itself in economic straits because of the Southeast Asian rice glut, the Soviet Union arranged purchases of rice, as well as barters of rice for heavy equipment, technical aid, 
Apart from these more or less conventional weapons of economic warfare, the Soviet state can use its monopoly of foreign trade to sell large quantities of goods at low prices, thus disrupting world markets Recently, Soviet sales of aluminum and tin and Rumanian sales of oil have raised fears that such a policy was being pursued. On the whole, however, the Soviet Government has used this tactic very sparingly and generally only where there has been some economic justification-the desire to get rid of surpluses or to break into markets otherwise closed. ${ }^{60}$ It is reasonable to suppose that the Soviet leaders recognize that, on the whole, a disruption of world markets is not to their own interest, both because the Soviet economy depends on such markets and because a deliberate policy of large-scale dumping would stimulate retaliatory measures on the part of other governments.

Finally, the Soviet state has the advantage of a unique type of influence on international trade-namely, that exercised by the communist parties of other countries. In some cases, West European communist parties participate directly or indirectly in private companies which import from, or export to, or finance trade with the Soviet Union or other communist countries.

II

\section{American Controls on Trade with the Soviet Union ${ }^{60}$}

Compared with domestic trade, American foreign trade is characterized by a relatively high degree of governmental control; compared with the Soviet system

and cement, although the Soviet Union has little need for Burmese rice. Id., Nov. 28, I955, p. $x$, col. 3 .

In 1955, when the world market for cotton had reached extremely low levels because of overproduction, the Soviet Union was able to relieve Egypt of surplus cotton stocks by extending credits and by a straight cotton-for-arms barter arrangement, although the Soviet Union was by then itself an exporter of cotton. In $x 955,26 \%$ of Egyptian exports went to East Europe and Communist China, as against $14 \%$ in 1954 . Id., Aug. 27, 1956, p. 3, col. 1. When Egypt was threatened with economic boycott and other sanctions following the Suez Canal nationalization in 1956, the Soviet Union, again, responded with trade offers and the sending of technical personnel.

The most direct use of trade as a political weapon is the imposition of a total or partial cmbargo purely as a retaliatory measure, with no relation to economic policy. The 1948 Yugoslav break with the Cominform was punished by a total trade embargo on the part of the other members of the Cominform. The impact of this action may be gauged by the fact that $50.7 \%$ of Yugoslavia's exports, and $95.6 \%$ of its imports, came from East Europe in that part of 1948 which preceded the break. Id., Dec. 28, x948, p. 1, col. 7. In September 1955 , Yugoslavia and the Soviet Union signed a new barter pact calling for exchanges of $\$ 70,000,000$ a year, id., Sept. 2, 1955, p. 2, col. 3, and the Soviet Union forgave a $\$ 90,000,000$ Yugoslav debt, as a token indemnity for the damage caused by the embargo. Id., July 28 , x955, p. 6, col. 2 .

Economic measures, again, reflected a political rapprochement when, in November 1956 , the Soviet Union settled accounts with Poland. Polish debts arising out of the use of credits granted by the Sovict Union, in full payment for coal delivered by Poland in 1946-53, were substantially reduced. Accounts in connection with railroad transport and various noncommercial payments were also revised in Poland's favor. See id., Nov. 19, 1956, p. I, col. 8.

For another example of withdrawal of trade for political reasons, denial of licenses for shipment of oil to Israel as an aftermath of the Israeli attack on Egypt in the fall of 1956 , see sipra note 34.

${ }^{60}$ In the case of aluminum and tin, Soviet policy seems to have been influenced in part by an acute balance-of-payments problem with the sterling area. Cf. Nove, Soviet Trade and Soviet Aid, Lloyd's Bank Review, Jan. 1959, p. I. In addition, the Soviet leaders may have been seeking to exert pressure for Soviet admission to the Intergovernmental Tin Agreement.

${ }^{\circ 0}$ United States export controls were analyzed shortly after passage of the r949 Export Control Act 
of foreign trade; however, the predominant characteristics of American trade are that it is carried on primarily by individual business firms, for profit, on the basis of market conditions, with prices and other contract terms in large part (though not entirely) free from control either by. government or by cartels or trade associations. It is its predominantly private, or market, character which determines not only the basic institutional structure of American foreign trade, but. also, to a large extent, the nature of the governmental controls upon it as well.

The legal controls imposed by the United States Government on trade with communist countries ${ }^{61}$ have been grafted onto legal controls imposed on foreign trade in general. The specifically anticommunist trade controls date only from 1948-49. ${ }^{62}$ Like the rest of American foreign trade controls, they do not present a harmonious, preconceived, and systematic set of directives; but are a mélange of particular measures designed to meet particular objectives and, sometimes, to satisfy particular interest groups. We shall consider them under the following headings: import controls, export controls, credit and exchange controls, restrictions on access to markets, and use of foreign trade to achieve political objectives.

\section{A. Import Controls}

\section{Customs duties}

The chief form of American import control is the tariff. Since I934, and especially since 1947, successive reductions in customs duties effected by the President under the-Reciprocal Trade Agreements Acts and through the General Agreement on Tariffs and Trade have made the American tariff a much less formidable barrier to foreign trade than it was in the I920's and early I930's.

In the case of imports from communist countries, however, Congress, in $195 \mathrm{I}$, as a result primarily of the Korean War, required the President to suspend, withdraw, or prevent the application of all tariff concessions granted since I930 to the Soviet Union and to "any nation or area dominated or controlled by the foreign government or foreign organization controlling the world Communist movement." ${ }^{\text {B }}$

The re-imposition of the r 930 tariffs upon imports from communist countries

in a student comment, Export Controls, 58 YAIE L. J. 1292 (1949), and in a short article by Ostroff, The Control of Exports, 13 FED. B. J. 52 (1952). See also Silverstone, The Export Control Act of 1949: Extra-territorial Enforcement, 107 U. PA. L. Rev. 33I (1959).' A valuable essay on the wartime and immediate postwar system of export licensing, is Robert C. Turner, Export Contror in the United States During the War and Postwar Perrods (1947). Apart from these items, there has been no analysis of the structure of American export controls in legal or economic periodicals, so far as the writct can discover, and there are no books on the subjèct. Export controls are described in quarterly reports on export control issued by the Secretary of Commerce to the President, the Senate, and the House of Representatives and in the Battle Act reports issued by the International 'Cooperation Administration and its predecessars. - The import and transactions controls on trade with communist countries seem to be analyzed nowhere. Indeed, government controls on foreign trade in general are; relative to their importance, one of the least studied branches of American law.

. " On the use of the term "communist," see supra note 2. American restrictions on trade with com.munist countries: do not extend to Yugoslavia.

${ }^{62}$ See infra note 87.

${ }^{\circ 3}$ Trade Agreements Extension Act of I95I, $\$ 5,65$ STAT. 73, I9 U.S.C. $\$$ I362 (1952). $\therefore . . "$. 
except Yugoslavia involved the termination or modification of various commercial treaties and agreements. ${ }^{64}$ In the case of the Soviet Union in particular, the President gave notice to the Soviet Government of termination of the Executive Agreement of 1937 in which the United States had granted to the Soviet Union unconditional and unrestricted most-favored-nation treatment with respect to customs duties, customs formalities, and laws affecting sale or use of imported goods within the country. ${ }^{65}$

As a result of the withdrawal of tariff concessions, Soviet manganese ore imported into the United States is taxed at the r930 rate of one cent per pound on the metallic manganese therein, whereas manganese ore from noncommunist countries is taxed at the rate of one-fourth cent per pound on the metallic manganese therein. Hewn or sawed timber imported from the Soviet Union is taxed at the r930 rate of one dollar per thousand board feet, whereas the same product imported from noncommunist countries is dutiable at twenty-five cents per thousand board feet. Essential or distilled oils imported from the Soviet Union are subject to a customs duty of twenty-five per cent ad valorem, whereas the customs duty on the same product imported from noncommunist countries is $61 / 4$ per cent ad valorem. ${ }^{60}$ These and other similar differences in tariff rates have been an important contributing cause of the decline of imports from the Soviet Union, although it should be noted that imports of Soviet products which are duty-free have also declined.7

American imports from the Soviet Union, in addition to being subject to the $193^{\circ}$ tariff rate, are exposed to several other tariff hazards which, though not erected expressly against communist countries, are apt to hit them with special force. These include antidumping duties, countervailing duties, and equalization duties. The

\footnotetext{
es Notice was given of termination of the 1937 commercial agreement with the Soviet Government, see infre note 65, and of the provisional commercial agreement of 1930 with Rumania, and the provisional commercial agreement with Bulgaria of $\mathrm{I} 932$ was denounced. Because most-favored-nation provisions were parts of treaties of friendship, commerce, and consular rights with Hungary and Poland, these states were notified to modify the treaties in question by terminating the relevant mostfavored-nation articles or to terminate the treaties as a whole. Because Czechoslovakia was a contracting party to the General Agreement on Tariffs and Trade, it was necessary to obtain a waiver of United States obligations to that country from the other contracting parties. See 13 RAmmond DenNETT \& Katherine D. Durant (Eds.), Documents on American Foreign Relations, January i-Decemper 31, I95I, at 316 (I952). By presidential proclamation, tariff concessions were suspended, "until reinstated," on imports from Albania, Estonia, the Kurile Islands, Latvia, Lithuania, Outer Mongolia, Rumania, the Russian Zone of Germany and the Russian Sector of Berlin, Southern Sakhalin, Tanna Tuva, and communist-controlled parts of China, Cambodia, Laos, Vietnam, and Korea. I6 Fev. Rec. 7635, 7636 (r95r).

${ }_{O E}$ The executive agreement extending most-favored-nation treatment to the Soviet Union, in return for Soviet commitments to purchase at least $\$ 40,000,000$ of American goods, was concluded on August 4, 1937, 50 Stat. 1619, E.A.S. No. ro5; and subsequently extended, for one-year periods, in 1938, 53 STAT. 1947, E.A.S. No. 132; in 1939, 53 STAT. 2404, E.A.S. No. 151; in 1940, 54 STAT. 2366, E.A.S. No. 179; in 1941, 55 Stat. 1316, E.A.S. No. 215; and in 1942, 56 StAT. 1500, E.A.S. No. 253. There are, at present, no commercial agreements in force with the Soviet Union, except lend-lease. U. S. Dep'T of State, Treaties in Force on JANUARY I, 1958, at 157-59 (1958).

${ }^{\circ 0}$ The 1930 rates are found in the Tariff Act of 1930, 46 STAr. 590, 19 U.S.C. $\$ 1001$, paras. 302, 58, 401. Information as to current rates was received from the Entry Division of the United States Customs House, Boston, Mass.

") See infra note 82 .
} 
American antidumping acts resulted from fears of West European dumping; they have been applied relatively rarely, ${ }^{68}$ and in no case to imports from a communist country. However, the basic test of the act-namely, that dumping occurs if the goods are imported into the United States at less than the price for which they are sold in the country of manufacture-threatens countries which do not have a free price system and a convertible currency; -and the provision that in the absence of a foreign or export price, the value of the goods may be determined on the basis of cost of production is susceptible of arbitrary application in the case of imports from a planned economy. ${ }^{60}$

Countervailing duties are a surtax, in addition to normal customs duties, imposed on imports whose exportation has been facilitated through a subsidy of the government of the foreign country. The additional duty is designed to neutralize the foreign subsidy ${ }^{70}$ Again, although in practice countervailing duties have not been levied upon imports from communist countries, they constitute a potential threat to trade with countries whose entire economy is, in one sense, subsidized.

Another type of tariff restriction which threatens the Soviet Union and other communist countries, for reasons similar to those indicated in the preceding paragraphs regarding antidumping and countervailing duties, is the provision of the I930 Tariff Act that imports produced in countries with costs of production lower than those prevailing in the United States are to be taxed so as to "equalize" the costs of production in the two countries. ${ }^{71}$ This provision does not apply to goods imported from countries with which the United States has a reciprocal trade agree-

${ }^{88}$ According to the Bureau of Customs of the Treasury Department, antidumping duties have been imposed only twice in the postwar period-on certain hardboard from Sweden, and on iron pipe from the United Kingdom.

${ }^{60}$ Antidumping Act, 42 Star. Iro (I92I), as amended, Ig U.S.C. $\$ \$$ I60-73 (1952). "Fair value" is defined in terms of a formula which compares the import price with the price at which the goods are sold for home consumption or for export in their home market. If sales volume in the home market does not form an adequate basis of comparison with sales in the United States, reference is made to third country sales. If third country sales do not form an adequate basis of comparison, or if figures are not available, cost of production is used. Tress. REG. $\$$ I4.7 (Supp. 1956).

The difficulty of applying these standards to the Soviet economy is readily apparent. The "official Soviet rate of four rubles to the dollar is inflated for some purposes. Ten rubles for a dollar are given to tourists and for "noncommercial transactions." Rubles are sold by private speculators in Western cities at rates ranging around 30 rubles for a dollar; however, the ruble is an internal currency only, and thus the "free" rate in forcign markets is for rubles which cannot purchase goods outside the Soviet Union and cannot legally be taken into the Soviet Union. Also domestic prices of many consumer goods are highly inflated by a turnover tax imposed on the transfer from the producing organization.

In Amtorg Trading Corp. v. United States, T.D. 45535, 61 Tress. Dec. 689 (I932), the court held that matches imported from the U.S.S.R. could not be subject to an antidumping duty, in part because there was no forcign value for such matches in the Soviet Union and there was no evidence in the record of the cost of production. This case is interpreted in Harry C. Hawkins, Commercial TREATIES AND AGREEMENTs 137 (I95I), as meaning that existing legislation is inadequate to prevent Soviet dumping. It should not be impossible, however, to present some evidence of Soviet cost of production; how to interpret the evideace is another matter.

${ }^{70}$ See Tariff Act of 1930, $\$ 303,46$ STAT. 687 , 19 U.S.C. $\$ 1303$ (1952).

${ }^{71}{ }_{46}$ STAT. 701, 19 U.S.C. $\$ 1336$ (1952). The Tariff Commission is required to report to the President findings with respect to differences in cost of production and to report such increases or decreases in rates of duty, up to $50 \%$; as it finds necessary to equalize such differences. However, the President has discretion with respect to approval of the Tariff Commission's recommendations. 
Hitert $;^{72}$ but since the denunciation of such agreements with the communist countries (èxíept 'Yùgoslavia) in $195 \mathrm{I}$, it hàs presumably' revived as to them, though it has irót been applied to them yet.

in: : . .......

2.Quotas and prohibitions.

- Quantitative restrictions upon imports play a relatively small role. in American foreign trade: Nevertheless, there are a few types of quota restrictions and prohibited imports which are an obstacle to trade with the Soviet Union and other communist countries.

$\therefore$ a. The President's power to impose restrictions upon goods imported in such quanitities as to constitute an actual or potential threat to the national security; though not especially addressed to communist countries and thus far not exercised against them, are potentially applicable to all imports from them. ${ }^{\mathbf{7 3}}$

b. United States Treasury Regulations issued in December 1950, under the Trading With the Enemy Act, prohibit the importation, without a license from the Secretary of the Treasury, of all merchandise the country of origin of which is Communist China or North Korea, and also of certain specified goods of which those countries are principal suppliers, from any country not named in the act. ${ }^{\mathbf{7 4}}$. Thus, cashmere may be imported from Iran freely; but not from any other country of the world without a license. Weasel may be imported from Canada, but not from any other country without a license. In fact, the Secretary of the Treasury does issue licenses for imports of the listed merchandise, and in the case of communist countries other than Communist China and North Korea, an informal quota system has-bèn established.75

\footnotetext{
$\therefore{ }^{2}$ See 48 STAT. 944, 19 U.S.C. $\$ 1352$ (1952). In addition to the provisions discussed above, the "President is authorized to impose additional duties on imports from a forcign country which discriminates, in fact, directly ö indirectly, by a law or administrative regulation or practice, against the 'exports and commerce of the United States, which is not equally enforced upon the like articles of every foreign counitry, or which places the commerce of the United States at a disadvantage compared with the commerce of any foreign country. 46 STAT. 704; I9 U.S.C. 51338 (I952). If, after the proclama"tion ' of such duties, the discriminating country maintains or increases its discriminations, the President is "authorized, if he deems it" consistent with the interests of the United States, to exclude products ofl'that cotuntry from importation into the United States. The additional dutics are not to exceed $50 \%$ ad valorem or its equivalent. This provision has apparently never been applied.

1 'Tráde Agteements Extension Act of $1955, \$ 7$ b, 69 STAт. 166, 19 U.S.C. $\$ 13522$ (Supp. V, 1958). Cf, Friedmann, Rights of Importers ander Section $7 b$ of the Trade Agreements Extension Act of 1955,25 GEo. WASH: L: REv. 427 (I957): The provision was retained in the Trade Agreements Extension Act of

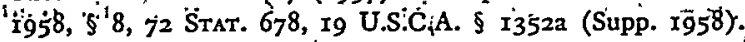

... Ts Trading With the Enemy Act of I9I7, 40 STAT, 4II, 50 U.S.C. App. $\$ \S$ I-40 (1952), as amended, $3{ }^{\prime}$ C.F.R. \$500.204' (Supp. r957). Following is a partial listing of the ' 42 items included in the regulation: aniseed, bambo, hog bristles, paint brushes, carpet' wool, cassia, cinnamon oil, eggs, feathers and dówn; firecrackers, floor coverings, goat skins, ginger roots, hats, jade stones, menthol, musk, tussah silk, "Chinése 'tea, tuna oil, walnuts, and yak" hair.

${ }^{75}$ Imports of the listed products from norcommunist-countries require a certificate of origin verified by the exporter's government. 'In i952, the Division of Foreign 'Assets Control of the Treasury Department established a quota system for traditional importers of cerțin goods from communist countries, éxcept China and North Korea. Each importer was given' a quiota based on the share of the total importation volume which his past import business reflected" in the base period 1946:50. 'Division officials state that this system was devised because 'is was 'considered that, although a "certificate" of
} 
c. One peculiar restriction directed against the Soviet..Union and Communist China was the prohibition in 195 $\mathrm{I}$ of the importation of seven kinds of furs and skins, but not of others, which are the product. of those two countries.70 This insertion into the Trade Agreements Extension Act of $195 \mathrm{I}$, which has been carried over into subsequent renewals of the Act, was the result of influence upon Congress by businessmen interested in selective prohibition of competing: imports, who were able to take-advantage of popular anticommunist feeling generated by the Korean War. This is the only example of an absolute import prohibition of particular Soviet products under American law.

d. Another type of import prohibition which was designed to affect the Soviet Union, as well as other countries, is the provision of the I930 Tariff Act barring imports produced by convicts or forced labor. ${ }^{77}$. This provision has occasionally been applied in practice. ${ }^{78}$ It was applied in I95I to Soviet crabmeat, ${ }^{79}$ and its existence constitutes a barrier to imports of other Soviet products, such as timber, which is produced in part by prisoners in the Siberian corrective labor camps.

Although the United States imposes quotas on the import of a few agricultural products (chiefly, cotton, sugar, wheat, butter, and some other-dairy products) and also of lead, zinc, and petroleum, these controls are not directed against particular countries and do not affect the Soviet Union or other communist countries substantially.

\section{Restrictions upon governmental purchases of foreign goods.}

In I933, Congress enacted the "Buy American" Act, which requires United States government agencies and business firms under contract with such agencies, in making purchases of goods for public use within the United States, to acquire "only such unmanufactured articles as have been produced substantially all from material produced in the United States," unless to do so would be "(a) inconsistent with the public interest or (b) unreasonably costly." 80 .This law was implemented in 1954

origin procedure would not be practicable with communist countries, established importers of these products should not be put out of business. No regulation has been published to this effect.

${ }^{70}$ Trade Agreements Extension Act of 195I, $\$$ II, 65 STAT. 75, I9 U.S.C. $\$$ I367 (1952): "The President shall . . . take such measures as may be necessary to prevent the importation of ermine, fox, kolinsky, marten, mink, muskrat and weasel furs and skins ... . which are the product of the Union of Soviet Socialist Republics or of Communist China." The President subsequently proclaimed that such imports are prohibited. I6 FED. REG. 7635,7636 (195I). .

77 "All goods .... produced ... in any foreign country by convict labor or/and forced labor or/and indentured labor under penal sanctions shall not be entitled to entry at any; of the ports of the United States, and the importation thereof is hereby prohibited. . . .

"'Forced labor,' as hercin used, shall mean all work or service which is exacted from any person under the menace of any penalty for its nonperformance and for which the worker does not offer himself voluntarily." . 46 STAT. 689, 19 U.S.C. \$ 1307 (1952). . ... . .

${ }^{78}$ Recently, certain products made. by prisoners in Mexican jails have been excluded, according to an official of the Bureau of : Customs. Once a. finding is made that the product is produced by convict or forced labor, it is excluded until satisfactory proof to the contrary is offered.

${ }^{70}$ I C.F.R. $\$ 12.42$ (1953); 16 FED. REG. 776 (195I).

80 "Buy American" Act $\$ 2,47$ STAT. I520 (I933), 4I Uं.S.C. $\$$ ioa (I952). 
by an executive order which stated certain price criteria for determining whether to purchase the product in the United States would be inconsistent with the public interest or unreasonably costly and which provided (section three): "Nothing in this order shall affect the authority or responsibility of an executive agency: (a) To reject any bid or offer for materials of foreign origin if such rejection is necessary to protect national security interests,-after receiving advice with respect thereto from the President or from any officer of the Government designated by the President to furnish such advice."

Thus, the present effect of the "Buy American" Act is to prevent imports under government contracts from any foreign country where such import would be against "the public interest," "the national interest," or "essential national security interests." The law could easily be interpreted as permitting a government agency to reject any bid or offer of products of the Soviet Union or any other communist country.

Apart from the above-mentioned controls, there is no restriction upon any import from the Soviet Union into the United States. The only restrictions which have actually been invoked are the imposition of quotas on forty-two products listed in the Treasury Regulations under the Trading With the Enemy Act as subject to licensing, the prohibition upon imports of seven kinds of furs and skins listed in the Trade Agreements Extension Act of 195I, and the exclusion of crabmeat as the product of forced labor. On the other hand, the withdrawal of tariff concessions from the communist countries (except Yugoslavia) is a serious barrier to the importation of many-though by no means all - of their products; ${ }^{82}$ and the power of the President to restrict imports when the national security so requires and the provisions for levying antidumping and countervailing duties, for "equalizing" the cost of production, and for barring products of convict or slave labor are a serious threat to imports from communist countries, though they have rarely been applied in practice, partly because of the small volume of such imports. Recent imports of Soviet benzene, Rumanian oil, and other products from the Soviet Union and East Europe have raised cries for invoking all these restrictions. ${ }^{83}$

${ }^{81}$ Exec. Order No. 10582, I9 FED. REg. 8723 (1954).

${ }^{82}$ The leyel of general imports from the U.S.S.R. dropped from $\$ 86,825,000$ in 1948 to $\$ 16,818,000$ in 1952. Nevertheless, imports of some commodities actually increased during the period $1948 \cdot 52$. Bristles imports rose from $\$ 210,000$ in 1948 to $\$ 8 \mathrm{r} 8,000$ in 1952 . Imports of certain commoditics principally manufactured by other European communist countries rose as well. $\$ 6,000$ worth of meats and sausage casings, mostly from Poland, were imported in 1948; by 1952, these imports had reached the figure of $\$ 7,259,000$. There was likewise an increase in the importation of fertilizers and fertilizer materials, from $\$ 18,000$ in 1948 to $\$ 2,746,000$ by 1952 . On the other hand, there were no imports of asbestos, which is on the free list and which was imported from the Soviet Union before the war $(6,000$ tons in 1936, according to Baykov, op. cit. supre note 1 , at 97). See 9 Mutual Defense Assistance Control Report [hereinafter cited as Ninth BattLe Act Report] app. E, table 4c (1957). In 1956, imports from the U.S.S.R. amounted to $\$ 24,443,000$; and in 1957 , to $\$ 16,512,000$. United States imports from the Sino-Soviet bloc totaled approximately $\$ 66,000,000$ in 1957 , as compared with approximately $\$ 73,000,000$ in 1956 , approximately $\$ 46,000,000$ in 1953 , and approximately $\$ 233,000,000$ in 1948 . II Mutuni Defense Assistance Control Report table 5 a (1958).

${ }^{83}$ Cf. N.Y. Times, March 2, 1959, p. I, col. 4. 
B. Export Controls

\section{Controls upon exports of strategic goods}

It is characteristic of the differences between the Soviet and the American systems of foreign trade that the Soviet Government may prevent exportation of any particular product to any particular country without enacting any prohibitory legislation or regulations, by the mere omission of the planning and administrative authorities to provide for exportation of the particular product to the particular country; whereas the American Government may not prevent private exportation of any particular product to any particular country without some prohibitory legislation or regulations. The elaborateness of such prohibitory legislation and regulations is, in part, an index of the extensiveness of the prohibitions, but it is also, in part, an index of the extent to which foreign trade operations are in private rather than governmental hands.

Export controls were imposed by the United States Government for the first time in I940, when the President was authorized to prohibit or curtail export of military equipment or munitions in the interest of national defense. ${ }^{84}$ In 1942, the list was extended to include all commodities and technical data, regardless of its significance for national defense. ${ }^{85}$ Although Congress removed many of the wartime powers of the executive in 1947 , the power to control exports was retained, though with some limitations and with the congressional injunction that it should be used sparingly. ${ }^{88}$ In 1949 , the present United States Export Control Act was passed, authorizing the President to "prohibit or curtail the exportation from the United States ... of any articles, materials, or supplies, including technical data, except under such rules and regulations as he shall prescribe."87 Under the rules and regulations laid down by the President, all exports, except those to Canada or a United States territory, require some form of license; however, most shipments can be made under a general license-that is, without obtaining specific prior permission. A shipment requiring a validated license can be made only after specific permission is obtained from United States Bureau of Foreign Commerce of the Department of Commerce, through its Office of Export Supply, a section established to administer export controls. Whether a general license or a validated license is required, however, the exporter must file a Shipper's Export Declaration describing the commodity to be exported and the name of the person to whom the commodity

al 54 StAT. 712, 714 (1940), 50 U.S.C. App. \$ II7I (1952).

${ }^{85}{ }_{5}$ STAT. 463 (1942), 50 U.S.C. App. $\$ 793$ (1952).

${ }^{80}$ Second Decontrol Act of I947, 61 STAT. 321, 50 U.S.C. App. $\$ 645$ (I952). Staffs of the Senate Foreign Relations Comm. and the House Forcign Affairs Comm., The European Recovery ProgramBasic Documents and Background Information, S. REP. No. III, 8oth Cong. Ist Sess. 18I (1947) declares that "pursuant to the clearly expressed will of the Congress, the executive branch has used sparingly the controls which were left on the statute books."

${ }^{87}$ Export Control Act of 1949, \$3, c. II, 63 SrAT. 7, 50 U.S.C. $\$ \$ 2021-32$ (I952). Under the Second Decontrol Act, supra note 86, shipments of all commodities to Europe and neighboring regions were brought under control as of March I, 1948. On April 30, 1948, the Secretary of Commerce reported that "primary attention has been devoted to shipments to Eastern rather than Western Europe," and that "all license applications to this area are subjected to close scrutiny." U.S. Dep't of Commerce, Export Control and Allocation Powers, April 30, 1948, p. 15. 
is ultimately consigned, as well as of:any intermediate consignee. Where a validated license is required, the application must state the cauntry: of ultimate destination, the ultimate consignee in the foreign country, and the end use of the product (for purchaser's own use, for resale in the open market, for new construction, for maintenance of existing facilities, for re-export, and if so, to what country, etc.), as well as other information, including "a detailed description of the specific use of the proposed exportation and its ultimate significance in the economy of the country of destination.". Moreover, the. applicant for a validated license must submit a statement from the ultimate consignee describing in detail the end use to which the commodity will be put, the types of customers to whom the resale will be made if resale is contemplated, etc. ${ }^{88}$

For licensing purpases the world is divided into two parts, Country Groups $O$ and R. Country Group $O$ consists of all of the-Western Hemisphere nations, except Canada. Country Group $R$.consists of all other countries in the world, except Canada. Subgroup A within Country Group R consists of nations with communist governments-specifically, Albania, Bulgaria, Communist China, Communist-controlled parts of Vietnam and Laos, Czechoslovakia, East Germany, Estonia, Hungary, Latvia, Lithuania, North Korea, Outer Mongolia, Rumania and the Soviet Union -but not Yugoslavia or, since 1957, Poland. ${ }^{89}$

Commodities subject to export control because they are in short supply (in January 1959, nickel alone fell into that category) or because they are considered strategic are placed on the so-called "Positive List." Certain goods on the Positive List-classified as $\mathrm{R}$ commodities-require a validated license if exported to $\mathrm{R}$ countries; other goods on the Positive List-classified as $\mathrm{RO}$ commodities-require a validated license if exported to either $\mathrm{R}$ or $\mathrm{O}$ countries. Until recently, all commodities exported to Subgroup A destinations, as well as to Hong Kong and Macao, required a validated license, whether or not they appeared on the Positive List; ${ }^{00}$ in April r956, a specific list of peaceful goods for export to European Russia (but not the Maritime Provinces-i.e. the Far Eastern seaports-of the Soviet Union) and East Europe was made subject to a general license, called General License Subgroup A. (GLSA) ?1

\footnotetext{
${ }^{88}$ The statement from the ultimate consignee may be by wire or cable. It must include ultimate destination, end use, and a description of the transaction sufficient to identify it as the same described in the application. If any changes are to be made, the consignee must promptly send a supplemental statement. There is, however, an alternative procedure' for exporters who have a continuing 'and regular relationship with an ultimate consignee involving "recurring orders for the same kind of commodities to the same destinations and for the same end uses. The exporter may submit a single statement signed. by the ultimate consignee covering all proposed shipments for the year. I5 C.F.R. $\$ 372.4$ (I957).

${ }^{30}$ I5 C.F.R. $\$=37$ I.3(a)(2). (1957), as amended, 22 FED: Reg. 7556 (1957).

${ }^{\circ 0}$ Id. $\S 371.2(\mathrm{c})(\mathrm{r})(\mathrm{ii})$. See also id. $\$ 372.3$. .

${ }^{91}$ Id. $\$ 37$ I:24. See U.S. Dep't Commerce,-Export Control, 4th quarter 1957, p. I5 for the list of commodities subject to the gerieral license GLSA. See also 15 C.F.R. \$371.51. (Supp. 1959). Another list is applicable for exports to Hong Kong (GHK); this list was extended to Macao on May 29, 1958.

"The establishment of this new general license in no way reflected a change in policy with respect to exports of strategic goods to the Soviet bloc.. Validated. licenses for European Soviet bloc destinations have continued to be required for all commodities not specifically. included on the "GLSA roster. The
} 
One of the chief practical difficulties for American manufacturer-exporters who wish to sell to the Soviet Union plant and machinery which is neither on the Positive List nor subject to general license GLSA is that they cannot be given advance assurance of a validated license; that is, the regulations of the Bureau of Foreign Commerce require that license applications be supported by a firm order. Since a considerable amount of time and money is often required even to do the preliminary work necessary to put in a bid, the license risk becomes a substantial obstacle. ${ }^{92}$

The Bureau of Foreign Commerce has virtually complete discretion in deciding whether or not to grant a validated license, within the general purposes of the Act. ${ }^{93}$ A system of administrative appeals from denial of a license is provided, with the final authority in a three-man Appeals Board designated within the Department of Commerce, but the discretion of the licensing authorities is so broad that it is hard to think of any ground on which their decision could be reversed, except refusal

main purpose of GLSA was to facilitate trade with the European Soviet bloc in nonstrategic and nonPositive List commodities by eliminating the burden on the American export community of receiving prior Government approval. All of the goods included on the GLSA roster are of the type that would be approved to these destinations under existing export licensing policy. [Query: would they have been under pre-existing policy ?-H.J.B.]

"Approximately 700 items in over 57 general commodity categories were included on the initial GLSA roster, including: beverages, certain rubber products, drugs and pharmaceuticals, fibers, wood and paper products, glass, clay products, cutlery, household goods, refrigeration équipment, office machines, dyes, leather, hides and skins, pigments, paints, certain chemical specialty, items, soil improvement compounds, soap and toiletries, photographic equipment, certain optical goods, musical instruments, toys, dental equipment, jewelry, lamps, sponges, notions, beauty and barber supplies and coin-operated machines.

"On June 20, x957, the Department announced an expansion of GLSA to include approximately 250 additional nonstrategic commodities.

"In another action, effective June 27,1957 , the Department removed a small number of items from the GLSA roster in order to prevent possible circumvention of U.S. Government policy providing for the denial of exports of subsidized Commodity Credit Corporation goods to the U.S.S.R. and other Eastern European countries (other than Poland). Commodities removed frm the GLSA roster under this action included rubber and rubberized piece goods, fabrics, clothing, shoes and miscellancous cotton textile products." U.S. Dep't of Commerce, Export Control, 4th quarter 1957, pp. 15, 16. (It is the policy of the Bureau of Foreign Commerce to deny applications for validated licensees to export, or authority to re-export, agricultural commodities and manufactures thereof to Subgroup A countries where the commodity is acquired directly or indirectly from the Commodity Credit Corporation or is shipped in substitution for such a commodity or is subsidized for export.)

In 1958, more goods were added to GLSA; and in, 1959, some goods have been subtracted from it. Most of the industrial equipment which the Soviet Union has sought to buy in the United States in recent years is neither on the GLSA list nor on the Positive List, and hence requires validated licenses. See infra note 135 .

A hitch to GLSA procedure is that the exporter must acquire a validated license for the export of any related technical data, aside from purely scientific material, that is not generally available.

${ }^{03}$ Cf. Address by Frank W. Sheaffer, Acting Director, Export Supply, U.S. Bureau of Foreign Commerce, at the Meeting of the American Management Association, Inc., New York City, Nov. 6, 1958.

${ }^{03}$ The general purposes are: "(a) to protect the domestic economy from the excessive drain of scarce materials and to reduce the inflationary impact of abnormal foreign demand; (b) to further the foreign policy of the United States and to aid in fulfilling its international responsibilities; and (c) to exercise the necessary vigilance over exports from the standpoint of their significance to the national security." 63 STAT. 7 (1949), 50 U.S.C. App. \$ 2022 (1952). See also 15 C.F.R. $\$ 372.1,372.5$ (1957): Since the Korean War, commodities controlled due to short supply have diminished almost entircly, and in January 1959, consisted solely of various types of nickel. See U.S. Dep't of Commerce, Export Control, 4th quarter 1958 , p. I6. 
to follow procedural requirements or a clear mistake in the findings of fact. ${ }^{04}$ No applicant has ever taken the denial or revocation of a license to court.

\section{Intergovernmental coordination of controls on trade with communist countries}

One of the legal problems involved in the rigorous system of United States export controls is the question of their extraterritorial effect. They subject to the penalties of the criminal law of the United States-with fines up to \$10,000 and imprisonment up to one year-any person who violates them, including any carrier or any consignee who diverts cargo contrary to the provisions of the export license. ${ }^{95}$ In fact, however, transshipment in violation of the United States Export Control Act by persons not subject to the jurisdiction of the United States cannot effectively be dealt with by criminal sanctions. Administrative denial of export privileges to such persons is a more effective means of enforcement, and hundreds of American and foreign merchants have suffered this penalty. ${ }^{90}$ In addition, the cooperation of foreign governments has been enlisted. Under a procedure introduced in 1952 for specific Positive List commodities exported to West European countries, the applicant for an export license must submit an import certificate (IC) issued by the government of the importing country; thus, the importer must make an official commitment to his government, under sanctions of penalties imposed by it, that the goods will not be used or re-exported or transshipped contrary to its regulations. Secondly, the United States authorities may, at their option, require a delivery verification (DV) in any case in which an import certificate is required and in certain other cases. The exporter obtains the verification from the importer, who receives it from his government. The importing country thus cooperates in the discovery of illegal transshipments. The procedure is referred to as IC/DV procedure. ${ }^{97}$ It should be noted, however, that IC/DV procedure is not applicable to goods which are not on the Positive List, but which require validated United States licenses.

A second problem, perhaps more political than legal, which is involved in the system of United States controls of exports of strategic goods is the question of the extent to which the United States may properly exert influence on other countries to maintain similar controls and to coordinate their controls with the American. The system of coordination of controls was established by the Mutual Defense Assistance Control Act (or Battle Act) of r95I, under which a coordinating commit-

"The regulations state that any person may appeal on the following grounds: "( $x$ ) The regulation or administrative action works an exceptional and unreasonable hardship upon him; or (2) The regulation or administrative action improperly discriminates against him." 15 C.F.R. \$ 383.1 (c) (1957).

${ }^{05}{ }_{15}$ C.F.R. $\$ 38$ I (1957); 63 STAT. 8 (r949), 50 U.S.C. App. 52025 (r952). The Act does not distinguish between American and foreign violators of its provisions.

so "The Export Control Investigation Staff of the Department of Commerce may initiate such proceedings against any person who appears to have violated any regulation related to export control. Hearings take place before Compliance Commissioners appointed by the Director of the Burcau of Foreign Commerce of the Department of Commerce. Complaints regarding administrative actions, or concerning regulations issued under the Export Control Act, may be brought before the Commerce Department's Appeals Board for final determination." U.S. Dep't of Commerce, Export Control, 3 d quarter 1958, p. I8. See 15 C.F.R. \$ 382.I (1957). Cf. Silverstone, supra note 60, at 338 et seq.

${ }^{07} \mathrm{IC} / \mathrm{DV}$ procedures are outlined in 15 C.F.R. $\$ 368,373.2$ (1957). 
tee of representatives of various countries is appointed to determine what goods should be considered strategic and what means should be adopted to prevent them from reaching communist countries. ${ }^{98}$ In fact, the system of controls of strategic exports is virtually the same in most West European countries. ${ }^{90}$ However, there is sometimes considerable diversity of opinion as to what exports should be restricted and what should not. Under the Battle Act, the President is authorized to withhold all economic assistance from any country which permits an export to any communist country of any goods "of primary strategic significance." ${ }^{\text {"100 }}$ Although a fairly high degree of harmony has apparently been maintained between the United States, Canada, and West Europe with respect to the Positive List of goods not to be exported to East European countries, there is a wide disparity concerning goods not on the Positive List, but, nevertheless, requiring validated licenses under American law. ${ }^{101}$ Moreover, the insistence of the United States on more severe restrictions in the case of Communist China has been rejected. ${ }^{102}$

${ }^{\text {os }}$ Multilateral organizations for international export controls have been functioning in Paris since January 1950. International lists of items for embargo, for quotas, and for surveillance have been established, although each participating country has its own national control list. The administrative machinery consists of the Consultative Group, which sits at intervals to coordinate strategic trade controls policy, and two subordinate committees which oversee continuing enforcement. One is the Coordinating Committec (COCOM); the other is the China Committee, (CHINCOM), established in 1952. COCOM applies trade controls to European communist countries; CHINCOM administers the more stringent controls on trade with communist countries in the Far East. In 1956, the following countries were members of the Consultative Group: Belgium, Canada, Denmark, Federal Republic of Germany, France, Greece, Italy, Japan, Luxembourg, Norway, Portugal, Netherlands, Turkey, United Kingdom, United States. See NiNTH BATTLE Act REPORT I5-20.

${ }^{\circ}$ Almost all the participating countries maintain the following trade-controls methods: 2 system of export licenses, which frequently includes end-use checks and IC/DV procedures; financial controls which require a check by officials on receipts and expenditures of foreign exchange; transit controls requiring permits and licenses for re-export, as well as checks on ultimate destination; and shipping controls aimed at preventing the carriage of strategic goods to Communist China, North Korea, or North Vietnam, as well as the denial of bunkering facilities to vessels engaged in such carriage. See NiNTH BAtTle Act Report app. C.

${ }^{100}$ Mutual Defense Assistance Control Act of 1951, $\$$ I02(b), 65 STAT. 644, 22 U.S.C. $\$$ I6rra (1952). Thus far, aid has never been withheld, although official portests have occasionally been made.

102 "On February 24 Anc. Etabl. Hofman, an import-export firm of Ghent, Belgium, and its owner, Andre Gryp, were barred from all U.S. export privileges for the duration of U.S. export controls for illegal diversion of U.S. boron products and paraffin wax valued at over $\$ 70,000$. Violations of U.S. export control regulations were further aggravated by false statements made to U.S. Government officials investigating the diversions. The firm's defense that it did not violate Belgian laws in transshipping the materials was rejected on the grounds that the recipients of U.S. goods who are informed of U.S. restrictions on their dispositions are bound by such restrictions." U.S. Dep't of Commerce, Export Control, Ist quarter I958, p. I9. (Emphasis added.)

102 Following the Korean armistice of July 2\%, 1953, CHINCOM members other than the United States expressed concern over the wide divergence between the China and East European control lists. These members have subsequently made extensive use of an exceptions procedure which has permitted them to export goods to Communist China which do not appear on the strategic lists for Eastern Europe. The items on which exceptions have been made include tractors, trucks, motor vehicles and parts, rubber, low-grade iron, and steel products. See Ninth BATtLe Act Report 37-42.

Because of limitations of space, discussion of United States restrictions on exports to and imports from Communist Chinz and North Korea is confined to the present footnote. In March I950, export controls on shipments to Communist China were made coextensive with the existing controls applicable to the European communist countries, according to $i d$. at 32 . Immediately following the invasion of South Korea, the United States, in June 1950, invoked a total embargo on exports to North Korea. I5 Fed. REg. 4I89 (1950). On December 3, I950, the United States imposed a complete embargo 


\section{Credit and Exchange Controls}

One of the more severe American restrictions upon trade with the Soviet Union is the Johnson Act of $\mathrm{I934}$, as amended, which makes it a crime for any individual, partnership, or private corporation or association to extend any loan to a foreign government which is in default in the payment of its obligations to the United States Government. ${ }^{103}$ The Act exempts public corporations created pursuant to special congressional authorization and seems to exempt corporations in which the Government of the United States exercises a controlling interest. ${ }^{104}$ The term "loan" in the Johnson Act has been construed not to apply to normal commercial credits, ${ }^{105}$ but it is considered to apply to credits beyond six months. ${ }^{108}$ This limitation of six months upon private credits is an obstacle to the supply of plant and equipment, where

on all exports to Communist China and Manchuria. Is id. at 8563 . The embargo has been rigorously enforced and is still in effect. As a result of this embargo, there has been practically no United States export trade with Communist China or North Korea since 1951. (There were shipments to Communist China of $\$ 6,000$ in 1954 , which represented the value of automobiles for use of a diplomatic mission; of $\$ 2,530$ in 1955, which represented shipments of printed matter under a general export license; and $\$ 12,073$ in the first three quarters of 1957 , which represented automobiles and parts for use of diplomatic missions of friendly foreign governments. U.S. Dep't of Commerce, Export Control, 3d quarter 1957, pp. I3-I.2.2

The prohibition of imports from Communist China and North Korea is effected by Treasury Regulations of December 17, 1950, issued under Section 5(b) of the Trading With the Encmy Act, which prohibits involvement in any financial or commercial transactions, by persons subject to United States jurisdiction, that relate to the transfer of money, credit or goods to or from Communist China or North Korea. 3I C.F.R. $\$ \S 500.201$, 500.204 (Supp. I957). In fact, such transactions have been authorized only in the most exceptional cases.

Thus, in contrast with its approach to trade with the Soviet Union and East European communist countries, the United States has sought a total embargo on trade with Communist China, rather than selective controls on strategic items. This is undoubtedly connected with ideas of moral outlawry stemming from the Korean conflict. An official report on the Battle Act states: "The reason for the United States' prohibition against all exports to Communist China was not that every kind of merchandise was considered to be directly -helpful on the battlefield. Rather the prohibition was based on a deep-felt conviction that an aggressor nation, engaged in fighting and killing the troops of the United States and other free countries, ought to be subjected to the maximum possible economic pressure, and that we ought not to supply its economy with any articles whatever, even civilian-type articles." 3 MUTUAL Defense- Assistance Report 34 (1953).

For reasons not explained, the embargo does not extend to imports from Outer Mongolia (chicfly furs and animal hairs), although it does extend to exports to Outer Mongolia. Cf. U.S. Dep't of Commerce, Export Control, $4^{\text {th }}$ quarter 1957, p. $4^{8}$.

${ }^{108} 62$ STAT. 744 (I948), I8 U.S.C. $\$ 955$ (1952). The penalties for violation are a fine of not more than $\$ 10,000$ or imprisonment for not more than 5 years or both.

10 Ibid. The language is somewhat obscure. The act applies to any "person," and "person" is said to include any "individual partnership, corporation, or association other than a public corporation created by or pursuant to special authorization of Congress, or a corporation in which the Government of the United States has or exercises a controlling interest through stock ownership or otherwise." The comma after the word "Congress," taken together with the absence of a comma after the word "association," would suggest that a corporation in which the Government of the United States has a controlling interest is contained within the definition of "person." However, the repetition of the word "or" sug. gests that a corporation in which the Government has a controlling interest is excluded. In terms of the purpose of the statute, it would seem that if public corporations created by Congress are excluded, Government-controlled corporations would also be excluded. Special legislation was enacted to exempt the Export-Import Bank from the Johnson Act. 59 STAT. 529 (1945), 12 U.S.C.A. $\$ 635$ h (1952).

${ }^{106} 38$ Ops. AtTy. Gen. 505 ( 1934 ).

${ }^{100}$ 'This is the opinion of the Attorney General's office, as given informally in response to inquiries by American businessmen. The point has never been tested in court, nor is it likely that any businessman would deliberately take the risk of such a test. 
longer credits are not abnormal. The Soviet Government is considered to be in default on its obligations to the United States Government for debts of the Russian Government incurred during World War I, for the value of relief supplies furnished on credit under authority of the Act of February 25, I9I9, and for obligations incurred during World War II under the Lend-Lease Act. ${ }^{107}$

Otherwise, there are no restrictions upon payments by American citizens to the Soviet Union or other communist countries, except Communist China and North Korea. There are, however, restrictions upon delivery of checks drawn on the United States Treasury to payees within the territories of all communist countries, except Yugoslavia and, since 1957 , Poland.

In 1940, Congress provided that no checks drawn against United States funds should be sent from the United States for delivery in a foreign country, where the Secretary of the Treasury had determined that conditions in that country were such that "there is not a reasonable assurance that the payee will actually receive such check or warrant and be able to negotiate the same for full value."10s The act does not affect checks in payment for salaries or wages, or goods purchased by the United States Government.

The Secretary of the Treasury has determined that "postal, transportation, or banking facilities in general or local conditions in Albania, Bulgaria, Communistcontrolled China, Czechoslovakia, Estonia, Hungary, Latvia, Lithuania, Rumania, the Union of Soviet Socialist Republics, the Russian Zone of Occupation of Germany, and the Russian Sector of Occupation of Berlin, Germany, are such that there is not a reasonable assurance that a payee in those areas will actually receive checks or warrants drawn against funds of the United States, or agencies or instrumentalities thereof, and be able to negotiate the same for full value."109 Checks drawn against the United States Treasury are, therefore, not delivered to payees within these countries. The removal of Poland from this list in 1957 was not explained by the improvement in "postal transportation, or banking facilities in general or local conditions" in that country. ${ }^{110}$

There are no federal restrictions upon private inter vivos transfers of currency to

${ }^{207}$ According to the Commissioner of Accounts of the Treasury Department, the June 30, 1958 indebtedness totals $\$ 573,270,081.23$, which is made up of principal in the amount of $\$ 192,601,297.37$ and accrued interest in the amount of $\$ 380,668,783.86$. The principal indebtedness consists of approximately $\$ 187,700,000$ cash advanced by the United States Treasury under the authority of the Liberty Bond Acts of I917, 40 STAT. 35, 288; approximately $\$ 400,000$ value of surplus war goods sold on credit under authority of the Act of July 9, I9I8, 40 STAT. 844 ; and approximately $\$ 4,500,000$ value of relief supplies furnished under the Act of Feb. 25, I9x9, 40 SrAT. II6r. The statement that the Soviet Union is also indebted to the United States under its lend-lease account has been made by the Office of the Legal Adviser of the Department of State in response to inquiries concerning the applicability of the Johnson Act to the Soviet Union.

${ }^{108} 54$ STAT. 1086 (1940), 31 U.S.C. \$ 123 (1952).

${ }^{100}$ 3I C.F.R. \$21I.3 (Supp. 2957). The Soviet Zone of Occupation of Germany, the Soviet Sector of Occupation of Berlin, Albania, and Bulgaria were added May Io, X950. Y5 FED. REg. 2938 (I950). Czechoslovakia, Estonia, Hungary, Latvia, Lithuania, Poland, Rumania, and the Soviet Union were added February 27, I95I. I6 FED. REG. I818 (195I). The other countries were added April 21, I95I. 16 FED. REg. $3479-3480$ (I95I).

${ }^{110} 22$ FED. REG. 4I34 (1957). 
any persons in any country except Communist China and North Korea.11 Thus, any private person in the United States may remit funds to any recipient in the Soviet Union, in any amount, by a simple authorization to a private bank, and without any possibility of governmental interference.

D. Restrictions upon Access of Soviet Trade Officials to United States Markets

\section{Exclusion of Soviet trade delegations}

In connection with diplomatic recognition of the Soviet Union in 1933, the United States refused the Soviet request to appoint to the Soviet Embassy a trade delegate with diplomatic status. It agreed only to the appointment of a Commercial Attaché, with the understanding that such officer would not engage in commercial transactions of any sort. ${ }^{112}$ The stated purpose of this restriction is to avoid problems arising from the claim of sovereign immunity in connection with trade transactions. ${ }^{113}$

Soviet foreign trade combines may buy and sell in the United States through commercial representatives. Also, there exists a New York corporation, the Amtorg Trading Corporation, whose shares are held in escrow in Moscow, which buys and sells in the United States as agent for Soviet foreign trade combines.

\section{Registration as foreign agents}

Under the Foreign Agents Registration Act of $193^{8}$, as amended, no person may act as an agent of a foreign government unless he has filed with the Attorney General of the United States a statement of his relation to his foreign principal, the nature of his business, his income and disbursements, and a detailed description of his activities. ${ }^{114}$ Under section 3 (d) of the Act, persons engaging "only in private, nonpolitical, financial, mercantile or other activities in furtherance of the bona fide trade or commerce of a foreign principal" are exempted from registration; however, the

\footnotetext{
${ }^{111}$ In most states, there are restrictions on testamentary transfers based on state statutes or state court decisions authorizing probate courts to withhold funds in estates if they find that the bencficiaries will not enjoy the benefit, use, or control of money remitted to them. . See, e.g., N.Y. Surn. Cr. Act $\$ 269$; N.J: Rev. Stat. $\$ 3 A$ : 25-Io (195I); Mass. Gen. Laws c. 206, $\$ 27$ A (r932); Ohio Rev. Codz Ann. \$ 2107.52 (Page I954); Conn. Gen. Stat. \$2946d (Supp. 1955); Mich. Stat. ANN. \$27.3178 (306a) (Supp. I955); Okla. Stat. tit. 6o, $\$$ I21 (I95I); cf. Cal. Prob. Code $\S \S 259$, 1026. Under these statutes, courts have often denied transfer of funds in estates to beneficiaries living in the Soviet Union and other communist countries. See, e.g., Matter of Best, 200 Misc. 332, ro7 N.Y.S. 2d 224 (Surr. Ct. I95I); In re Mazurowski, 33I Mass. 33, rr6 N.E.2d 854 (I954). Cf. Heyman, The Non-Resident Alien's Right to Succession under the Iron Curtain Rule, 52 Nw. U. L. REv. 221 (1957); Scheller \& Mayda, Payment of Estate Shares to Beneficiaries Behind the "Iron Curtain," Wis. Bar. Bull., June 1955, p. 17; Chaitkin, The Rights of Residents of Russia and Its Satellites to Share in Estates of American Decedents, 25 So. Carif. L. Rev. 297 (1952); Note, Beneficiaries Behind the Iron Curtain, 7 W. Res. L. REv. I79 (I956).

${ }^{112}$ See. Memorandum by the Department of State to the Soviet Embassy, Dec. 20, I933. U.S. DEP'T of State, Foreign Relations of The United States, The Soviet Union 1933-1939, at 5I (1952).

${ }^{113}$ During World War II, there was an official Soviet Government Purchasing Commission in Washington which handled all orders for military and other goods shipped under the Lend-Lease Act. Disputes arising from the Commission's activities were resolved through diplomatic channels.

${ }^{114}$ Foreign Agents Registration Act of $1938, \S 2,52$ StAT. 632, as amended, 22 U.S.C. $\$ 612$ (1952).
} 
Attorney General has a wide discretion to deny the exemption to persons who carry on "any political activity," including lobbying, propaganda, collection of intelligence, and similar activities. ${ }^{115}$ Since 1949 , Amtorg personnel have been required to register and to report all their activities in detail.

\section{Travel restrictions}

On June 7, I94I, the United States imposed retaliatory travel restrictions on Soviet officials, but these were withdrawn after the German attack on the Soviet Union on June 22, I94I. ${ }^{116}$ In I952, retaliatory travel restrictions were again imposed on Soviet officials; $;^{117}$ and in 1955 , they were imposed on all resident Soviet citizens who are in possession of valid passports issued by the Government of the Soviet Union, other than United Nations employees. ${ }^{118}$ Under the restrictions, Soviet citizens are prohibited from travelling to certain cities and certain areas of the countrychosen to correspond roughly to cities and areas of the Soviet Union to which American citizens are not allowed to go. However, the restrictions are not absolute; Soviet citizens who are temporarily admitted to the United States for some specific purpose "may be granted access to a closed city or area if their presence in such city or area is germane to the purpose of the visit for which they were admitted." Evis Even for resident representatives, a showing of adequate business reasons for presence in a closed zone would probably result in a temporary accommodation.

\section{Visa requirements}

The Immigration and Nationality Act of 1952 provides that aliens who are members of a foreign Communist Party are ineligible to receive visas and are excluded from admission into the United States, but that this provision is inapplicable "upon a basis of reciprocity, [to] officials and employees who have been accredited by a foreign government recognized de jure by the United States, who are accepted by the Secretary of State."120 In effect, this means that officials of foreign trade combines or other economic organizations of communist countries (including Yugoslavia) would be eligible to receive visas only by permission of the Secretary of State.

Under the same Act, every alien who applied for a visa was required to be registered and fingerprinted, except that the requirement could be waived, at the discretion of the Secretary of State, for officials and employes of foreign governments. ${ }^{121}$ Representatives of trading organizations of the Soviet Union and other countries of planned economy are "officials" within the meaning of the Act. In I957, the fingerprinting requirement was waived in the case of most nonimmigrant aliens. $^{122}$

\footnotetext{
${ }^{110}$ See 28 C.F.R. $\$ 5.303$ (I949). "Political activity" is defined in 28 C.F.R. $\$$ 5.roo(a)(ii) (I949). ${ }^{110}{ }_{4}$ Dep't State Bull. 702, 748 (I94I).

${ }^{117}$ Dep't of State Press Release No. I81, March ro, 1952.

${ }^{218}$ Id. No. I, January 3, I955.

110 lbid.

${ }^{120}$ Immigration and Nationality Act of I952, $\$$ Ior, 66 SraT. I66, 8 U.S.C. $\S \operatorname{Iror}(15)(A)(i i)$ (I952).

${ }^{121}$ Id. $\$ 221,66$ STAT. I9I, 8 U.S.C. $\$ \S$ I20I, 120I(b) (I952).

${ }^{129}$ This waiver was by amendment of 22 C.F.R. \$ 4I (1958). See 22 Fed. REg. 81rg (I957).
} 


\section{E. Use of Foreign Trade to Achieve Political Objectives}

The United States consciously seeks to adapt its foreign trade to its over-all foreign policy. It is handicapped in this, however, by the fact that the Government has at its disposal very few means by which it can directly allocate foreign trade. It can sell agricultural surpluses, purchased from farmers under price-support legislation, to countries whose foreign policy it is seeking to influence. It can extend technical assistance by sending specialists and setting up capital development projects. Such direct positive governmental assistance forms a relatively small part of our total aid. The chief means by which the United States can extend foreign economic aid is by government grants and by credits to foreign governments to finance American exports. For the past decade, Congress has voted several billion dollars each year for such aid. Most of this money has been spent to improve the military and economic condition of West European allies. Some aid, however, has gone to communist countries. Thus, in 1948 and thereafter, the United States gave credits to Yugoslavia which enabled that country to obtain vitally needed commodities which she had hitherto received from other communist countries; and in 1957 and 1958, credits were extended to Poland to enable that country to purchase surplus farm goods and mining machinery. ${ }^{123}$

${ }^{123}$ The first agreement between the United States and Communist Poland, concluded on June 7, 1957, provided for the sale and shipment of $\$ 18,900,000$ of surplus agricultural commoditics, with payment in Polish zlotys, pursuant to tit. I of the Agricultural Trade Development and Assistance Act of 1954, as amended. The zlotys were to be deposited to the account of the United States, and on the same date of such deposit, were to be converted and transferred to a special dollar denominated account to the credit of the United States in the National Bank of Poland. Poland agreed to purchase for dollars the balance of zlotys unexpended in 1962 , to the extent of $\$ 726$,000 annually. Surplus Agricultural Commodities Agreement With the Polish People's Republic, June 7, 1957, [1957] 8 U.S.T. \& O.I.A. 799, T.I.A.S. No. 3839 (effective June 7, 1937).

In addition, the United States loaned Poland $\$ 30,000,000$, administered through the Export-Import Bank, for the purchase of surplus products and mining machinery. This line of eredit is repayable at $4 \frac{112 \%}{2}$ interest in dollars over a 20 -year period, beginning in 1962 . N.Y. Times, June 8,1957, p. 1, col. 5.

On Aug. 14, 1957, the June 7th agreement was supplemented by the additional financing by the United States of wheat and cotton sales totaling $\$ 46,100.000$, in return for zlotys under the same arrangement. Agreement Amending the Surplus Agricultural Commodities Agreement With the Polish Pcople's Republic of June 7, 1957, [1957] 8 U.S.T. \& O.I.A. 1289, T.I.A.S. No. 3878 (effective Aug. 14, 1957).

On Feb. 15, 1958, a second surplus agricultural commodities agreement was entered into, with the United States undertaking the financing of the sale of $\$ 73,000,000$ of commodities and transportation, with payment in zlotys under arrangements similar to those of the June 7, I957 agreement. Poland agreed to buy back for dollars unexpended zlotys at the annual rate of $\$ 2,8 \times 0,000$, beginning in 1963 . Surplus Agricultural Commodities Agreement with Poland, Feb. 15, 1958, T.I.A.S. No. 399x (effective Feb. I5, 1958). At the same time, a second loan of $\$ 25,000,000$ was extended to Poland for the purchase of raw materials and machinery for consumer goods industries. The loan, like the one in 1957, will come from the President's special assistance fund and will be administered by the ExportImport Bank. N.Y. Times, Feb. 16, 1958, p. 1, col. 8.

Also, Poland has now been placed in a separate category from other East European countries for export control purposes. An official of the United States Department of Commerce has stated: "Except for a list of approximately 50 commodities, and except for unpublished technical data, exports to Poland are subject to no more restriction than, say, to England or Italy. A considerable sum of money has been loaned to Poland by the United States, and considerable quantities of modern equipment have been approved against these credits for export under approved government programs to further the industrial development of Poland, and to increase the economic well-being of her people." Address by Frank W. Shaeffer, supra note 92.

In addition to 63 items on the so-called "Polish exceptions list," I5 C.F.R. $\$ 371.52$ (1957) (to which 
Conclusions

It is apparent from the foregoing analysis that the existing legal framework is hardly adequate to support normal trade relations between the Soviet Union and the United States. The legal obstacles to trade-on both sides-are due in part to the strained political relations between the two countries, and in part to differences in their respective systems of trading.

On the Soviet side, we have seen that despite important adaptations of the system of foreign trade to the requirements of the international commercial and legal order, there is need for still further adjustment:

I. Problems created by the doctrine of sovereign immunity, though substantially reduced by the establishment of legally responsible foreign trade combines, are not entirely eliminated.

2. Although the combines have accepted the basic concepts and institutions of commercial law and custom common to the international trading community, the foreign trader who deals with them must still contend with certain features of Soviet law arising from the fact that their representatives are state officials subordinate administratively to the Ministry of Foreign Trade.

3. Despite the apparent fairness of reported decisions of the Soviet Foreign Trade Arbitration Tribunal, and assuming its impartiality in fact, there remains an open question of its legal capacity for impartiality or, to put it more precisely, the potentiality of abuse of its independence.

4. The insulation of the ultimate consuming or producing enterprise from the foreign exporter or importer, although occasionally overcome in practice, is fostered by the monopolization of foreign trade transactions by a relatively small number of central agencies which are essentially brokers.

5. The secrecy of Soviet authorities concerning the details of foreign trade planning and concerning Soviet market conditions, though somewhat relaxed in recent years, is a substantial obstacle to normal trade relations.

6. Similarly, the virtual impossibility for foreigners to establish branch offices, licensing arrangements, and other means of maintaining close and enduring contacts with Soviet industry is a substantial obstacle to normal trade relations.

Every one of these obstacles could be reduced, and some of them could be removed entirely, without making any fundamental change in the Soviet system of trading:

85 commodities were added and from which 30 were subtracted in January, 1959, as a consequence of the removal of some 300 commodity entries from the Positive List in November 1958, Bureau of Foreign Commerce, Current Export Bulletin No. 8ro, Jan. 8, 1959), and to unpublished (or not generally available in published form) technical data, id. $\S 385.2$, to which Mr. Shaeffer referred, Poland is also subject to restrictions on ship stores, plane stores, and crew and registered carrier stores, id. $\$$ 37r.r3 and 372.7, and on shipments of limited value. Id. $\$ 37$ r.xo; cf. also id. $\$ 371.9$.

Poland has been removed from the list of countries to which the Treasury prohibits the sending of government checks. Supra note iro. 
x. By treaty, the Soviet Union could waive all claims of sovereign immunity by its trading organizations. ${ }^{124}$

2. In some instances by legislation and in others by contract, various features of Soviet law which are inappropriate for international trade could be eliminated. ${ }^{125}$

3. Settlement of disputes could be handled by a special arbitration board consisting of American, Soviet, and third-country members; $;^{128}$ at the very least, the panel of the Soviet Foreign Trade Arbitration Commission should contain a substantial number of Westerners who would be known and respected by Western businessmen.

4. The decentralization of Soviet industry and construction which is now taking place could be extended to Soviet foreign trade, and some state industrial enterprises, at least, could be given direct access to foreign markets. ${ }^{127}$

5. A great deal more information could be made available to foreigners regarding both the details of the planning system and the details of the plans themselves.

6. Branch offices and licensing arrangements could be permitted to foreign firms, and some protection, at least for foreign patents could be assured. ${ }^{128}$

All of these steps would contribute to the creation of a climate favorable to expanded commercial relations, without altering the basic characteristics of the Soviet system of foreign trade.

On the American side, the time has come to weigh the utility of each of our various. types of restrictions from both a military and an economic viewpoint, and to attempt to establish a system of controls which will make sense from both viewpoints. On the import side, virtually all special restrictions directed against communist countries could be removed without any adverse effect upon our military or economic welfare. If there was any military or economic justification for such restrictions in the past, based upon the existence of a dollar shortage in other countries, such justification no longer exists: the communist countries can sell their furs, oil, chrome, chemicals, cameras, etc., elsewhere than in the United States with more or less equal advantage to themselves and with adverse effect upon us to the extent that we wish to purchase such goods. An exception to this is manganese and other strategic goods for whose supply we should not become dependent upon

124 Cf. discussion supra $484-85,486,490$.

$125 \mathrm{Cf}$. discussion supra 490-92.

${ }^{128}$ Cf. discussion supra $485,493-95$. The establishment of a joint Soviet-American arbitration commission was proposed to the Soviet-Foreign Trade Arbitration Commission by the American Arbitration Association in 1946. American Arbitration Association Press Release, May x, 1946.

${ }^{227}$ Cf. discussion supre 497-99. The decentralization of industry has consisted chiefly in the establishment of over Ioo economic regions in the Soviet Union, with the transfer of administration of many industries from central ministries in Moscow, many of which have been dissolved, to regional economic councils. Central control is maintained through representation of the regional economic councils on the councils of ministers of the 16 republics and through representation of the republican councils of ministers on the Council of Ministers of the Soviet Union. There has been no talk of decentralization of foreign trade in the Soviet Union (though there has been such talk, and some steps in that dircetion, in Poland), beyond informal reports that some regional economic councils have the right to resist Ministry of Foreign Trade orders.

${ }^{128}$ Cf. supra note 53. 
the communist countries; the import of such goods should be limited, however, by quotas rather than by customs duties, since thereby we would be in a position to import them in small enough quantities to do us no harm and some good. The principal changes required to assure equality of treatment would be the elimination by Congress of tariff discrimination against products imported from communist countries and of the prohibition against the importation of certain kinds of furs and skins. ${ }^{120}$

With respect to exchange controls, the administrative restriction upon the sending of Treasury checks to East European countries (other than Yugoslavia and Poland) affects chiefly persons entitled to American veterans' benefits, United States Gov. ernment pensions, and the like, and hence the elimination of this restriction would not affect trade directly; it would, however, help to create a more favorable political climate for trade.

As for American exports to communist countries, our, Positive List could be brought into harmony with that of Canada and of the West European countries, and general license privileges could be granted for all goods not on the Positive List, without, it would seem, jeopardizing our security. Not much is gained from a security standpoint by preventing the Soviets from buying here what they can büy from our Canadian or West European competitors. ${ }^{130}$ To eliminate the Positive List altogether, however, as the Soviet leaders wish us to do, would involve the danger that private exporters could sẹll to the Soviet Union or other communist countries goods of military importance.

The Soviet Government does not need to use the device of a:Positive List, for it directly controls all Soviet exports and imports. It is, therefore, not bound by conceptual distinctions between strategic and nonstrategic items. It can export strategic goods when it is strategic to do so, and can import nonstrategic goods when it.is strategic to do so. The United States Government exercises, for the most part; only indirect, or secondary, controls on exports; it either grants or denies license applications of private exporters. Its general standard for granting:or denying such applications is the broad one of "national security interests," and to make this standard meaningful, it declares in advance that certain exports are "peaceful" and others are "strategic" and the rest are in between. But however conscientiously such a classifica. tion of exports may be made and administered; it is bound to be unsatisfactory. Aluminum was until the end of $195^{8}$ on the Positive List, but in $195^{8}$, the Soviet Union exported aluminum in large quantities and at low prices. Benzene, although

${ }^{120} \mathrm{Cf}$. discussion supra 505-09. The present laws on dumping, on countervailing duties, on equalizätion of costs of production, on retaliation against discrimination, on private loans to foreign governments, and on governmental purchases are not directed solely, or even principally, against the Soviet Union or other communist countries, so that their existence cannot be considered as in itself discriminatory. Whether they make sense is another question. Treasury licensing of imports of specific goods from communist countries is designed to prevent the transshipment of those goods from Communist China;" as indicated supra note r02, our policy regarding trade with Communist China and North Korea is regarded as distinct from our policy regarding trade with other communist countries.

${ }^{130}$ Cf. N.Y. Times, March 14, 1958, p. 36, col. 8; id., July 13, § 3, p. I, col. 2; id., Aug. 21, 1958, p. 2, col. 4 ; id., Sept. 27 , p. 27 , col. 3 . 
not on the Positive List, is also not on the GLSA list and hence requires a validated license for export to the Soviet Union, but that country recently contracted to sell Dow Chemical Company benzene to the value of some $\$ 13,000,000.131$

Above all, the concept of a Positive List of strategic exports as the major device for governmental control of trade with the Soviet Union fails to meet the problem of reciprocity, in the sense of mutual advantage to the two countries. An American trader who buys Soviet furs, for example, is rarely in a position to ask the Soviet Government, "Why won't you buy American cosmetics?" The American trader is properly concerned only with his own business. ${ }^{132}$ Soviet buyers and sellers, on the other hand, operate under a foreign trade plan which is designed to serve the national interests of the Soviet Union. To the extent, then, that the Soviet Union trades with American firms, it is planning American foreign trade. Our export licensing system sets limits to our trade with the Soviet Union, but it does not exert a positive influence on that trade; it affects only remotely what the Soviets sell to us, and only indirectly what they, in fact, buy from us.

The United States Government could protect our national interests, and at the same time promote American-Soviet trade, by entering into a bilateral trade agreement with the Soviet Government authorizing the exchange of particular goods in particular quantities over a particular period of time. Whether such an agrecment provided for a relatively small or a relatively large volume of trade, it would have advantages for both sides. From the Soviet viewpoint, it would eliminate difficultics created by the complexity of our export-licensing system, since the United States Government would promise in advance to issue licenses within the limits of the trade agreement; and it would enable the Soviet Ministry of Foreign Trade more effectively to gear its trade with the United States into the Soviet planning system. From the American viewpoint, it would ensure that our trade with the Soviet Union is to the advantage of the nation as a whole, and not merely of those particular exporters or importers who are now able to get through the meshes of both Soviet and American controls.

By a trade agreement of the kind suggested, the American national interest could be promoted in the following ways:

r. Our Government could assure the supply into this country of some Soviet

${ }^{222}$ Cf. N.Y. Times, Nov. 29, I95ं8, p. 1, col. 5. Benzene was also imported from the Soviet Union in relatively large quantities in $1956(\$ 10,532,000)$ and $1957(\$ 6,299,000)$. U.S. Dep't of Commerce, Export Control, 3d quarter 1958, p. 34 .

${ }^{239}$ Occasionally, such a private arrangement is worked out. Thus, it was announced recently that a New York export-import concern had arranged for the sale to the Soviet Union of 20,000 tons of coldrolled steel sheets and the simultaneous purchase from the Soviet Union of 80,000 tons of high-grade metallurgical chrome ore used in making stainless and other specialty steels and high-temperature alloys. The New York broker stated that the transaction "technically was not a barter arrangement," since he paid for the ore and the Soviets paid for the steel, both sales being at "going world prices," but that the cost of the ore was about that of the steel. N.Y. Times, Jan.,9, I959, p. 35c, col. 4. One may surmise that it was easier for the broker to obtain the. United States export license for the steel in view of the concurrent import of the chrome. 
products which our importers want but which are not now available because the Soviets are selling them under trade agreements with other countries.

2. It could assure the purchase by the Soviets of some products they now procure from our exporters' competitors in other countries.

3. It could prevent purchase by the Soviets of very small quantities of machinery bought merely as models to be copied-a practice of which we often complain.

4. The extra bargaining power which the Soviet combines derive from their monopolistic character could be partially offset.

5. An even more efficient protection would be provided against export of strategic goods than is possible under our present system of controls, since our Government could determine in advance which products desired by the Soviets it would be willing to license.

6. Some of the obstacles to normal trade relations created by the Soviet system, listed above, could be reduced.

In solving some of the old problems, such a trade agreement would also create new ones. The most our Government would or should be willing to do is to agree to issue export licenses to private traders for the products listed in the agreement and-Congress willing-to remove discriminations against Soviet imports. ${ }^{133}$ Whether the Soviet Government would be willing to make firmer commitments, in view of its administrative control over its export-import combines, would be a matter for negotiation. In any case, problems of fulfillment of the agreement would inevitably arise. It would remain for our private traders to make contracts with the Soviet export-import combines, in which matters of price, quantity, quality, time and method of delivery, and other conditions of particular transactions would have to be worked out. It would be necessary to devise proper techniques for counteracting any delinquency in the execution of contracts and to ensure that the deliveries ultimately corresponded as nearly as possible with the terms of the agreement.

In June $195^{8}$, Soviet Premier Khrushchev proposed such a Soviet-American trade agreement in a letter to President Eisenhower. ${ }^{134}$ The letter listed types of industrial products of a peaceful nature which the Soviet Union would like to purchase in the United States, and types of products which the Soviet Union would offer to sell

\footnotetext{
${ }^{133}$ According to one view, a most-favored-nation clause in treaties between planned and free-market economies benefits only the planned economies, which may continue to discriminate administratively against imports from a country while granting tariff equality. See Domke \& Hazard, State Trading and the Most-Favored-Nation Clause, 52 AM. J. INT'L L. 55 (1958). It is submitted that the authors have taken too narrow a view of the function of the most-favored-nation clause. Historically, it is true, its primary function has been to assure equality of treatment with respect to customs duties, and this remains its primary function for a country like the United States, in which the tariff is the primary means of import control. The principle of nondiscrimination, however, which underlies the most-favored-nation clause, may easily be extended to controls other than tariffs. In trade agreements between planned and free economies, the most-favored-nation clause should be particularized; that is, reciprocity should be secured by particular nondiscrimination clauses relating to such matters as granting of visas, access to courts, access to markets, use of shipping, and the like, as well as to customs duties.

33139 Dep't State Bull. 200 (I958).
} 
in the United States. ${ }^{135}$ It also proposed that American specialists be sent to the Soviet Union and that licensing agreements could be made in individual cases. It suggested that a very large expansion of Soviet-American trade would raise questions concerning the possibility of long-term credits, but added that "of course, it is possible to begin the development of commerce on the basis of reciprocal deliveries."

The letter also stated: "It is also obvious that the development of trade between the U.S.S.R. and the U.S.A. will require the creation of the requisite contractual and legal basis. The question of creating such a basis, as well as that of implementing a program for purchases of American goods and deliveries of Soviet goods, and also payments for them, could, provided the Government of the U.S.A. consents, be subject to intergovernmental negotiation."

President Eisenhower's reply stated that "the United States favors the expansion of peaceful trade with the Soviet Union," but it rejected the bid for an intergovernmental agreement. "As you know," the President wrote, ${ }^{138}$

United States export and import trade is carried on by individual firms and not under governmental auspices. There is no need, therefore, to formalize relations between United States firms and Soviet trade organizations. Soviet trade organizations are free right now, without any need for special action by the United States Government, to develop a larger volume of trade with firms in this country. . . F Furthermore, many of the more important Soviet trade items mentioned in your letter are accorded duty-free entry into the United States. While the extension of long-term credits for Soviet purchases in the United States would raise complex legal and political questions, the normal commercial credit terms presently available to Soviet trade organizations permit the further expansion of trade between our two countries.

The President added: "I am asking the Department of State to examine the specific proposals contained in your letter and to communicate further with your government." To date, there has been no announcement of a further communication by the Department of State.

While it is undoubtedly true that Soviet-American trade could be expanded without any changes in existing American governmental or legal policies or practices, it

\footnotetext{
${ }^{235}$.The proposal stated that it was directed not to trade in armaments or plant equipment for military production, but to industrial equipment for production of consumer goods and to nonmilitary industrial products and finished goods, including the following types: refrigeration equipment; installations for air conditioning; equipment for the cellulose, paper and wood-processing industries, textile, leatherfootwear, and food industries; television equipment; equipment for manufacture of packing materials; packing, packaging, and automatic-vending machines; pumps and compressors; machincry for the mining industry, for the manufacture of building materials, and the mechanization of construction; hoisting, transporting, and other equipment; equipment for rolling ferrous metals; pipes for city gas lines; and various chemical products, medical equipment, medicines, and certain consumer goods.

Soviet products which the proposal stated might be exported to the United States included "manganese and chromium ores, cellulose and paper products, ferrous alloys, platinum, palladium, asbestos, potassium salts, lumber, certain chemical products, furs, and other goods," as well as "a number of types of modern machinery, and equipment which could be of interest to American firms." Also the proposal stated that "If American firms manifest an interest, the Soviet Union could also consider the question of developing the extraction of iron ore for delivery to the U. S. A." Ibid.

${ }^{136} \mathrm{Ibid}$. The legal difficulties apparently consist in the provisions of the Johnson Act. Cf. stupra 5I6-r7 and notes 103-07.
} 
is also true that American restrictions place severe obstacles in the path of such an expansion. The products which Khrushchev proposed to buy from American firms are, for the most part, neither on the Positive List of strategic exports nor on the GLSA list of "peaceful" goods subject to general license for the Soviet area. They require, therefore, a validated license, and there can be no advance assurance that such licenses will be granted. Since they are, for the most part, industrial plant and equipment, it would be necessary for American manufacture exporters to conduct elaborate preparations in order to make bids; few firms would be willing to undertake the expense of making such bids without advance assurance that export licenses would be granted. Similarly, with respect to Soviet exports to the United States, although it is true, as the President stated, that some of the products listed by Khrushchev are duty-free, others are subject to a tariff rate higher than that which is applied to the same products imported from other countries; and even those which are duty-free may fall within the various restrictions which have been mentioned. ${ }^{13 \pi}$

The peculiar problems of creating a proper legal framework for trade between the Soviet Union and the United States have a general significance, for they demonstrate that the principles of free multilateral trade and the policy of seeking to reduce quantitative restrictions and discriminatory practices in international trade, though valid for trade among market economies, are inappropriate to commercial relations between communist and noncommunist countries. The principles and policies of the General Agreement on Tariffs and Trade, designed as a framework for trade relations among countries whose trade is carried on primarily by private traders, do not meet the problems of trade relations between such countries and other countries. whose commerce is itself a governmental function. Indeed, the United States has by its existing restrictions abandoned both the principle and the policy of free trade with communist countries. ${ }^{138}$

Because we cannot cope with the hard fact of the appearance of the Soviet state monopoly on world markets without some form of governmental control does not mean, however, that we must develop a "Government overseas trade monopoly to. compete with the Soviet monopoly on equal terms," as some have proposed. ${ }^{139}$ This. would be to jump from the frying pan into the fire. The better alternative is to try to turn down the heat. The Government should try to help businessmen, both in dealing with the Soviets and in competing with them; it can do so without going into business itself.

An intergovernmental trade agreement providing for a program of mutual exchanges of particular goods over a particular period would require the creation of a 137 Supra 505-10.

${ }^{258}$ This was expressly recognized by the dissolution of GATT commitments between the United States and Czechoslovakia. 2 GATT, BastC INSTRUMents AND SEL ECTEd Documents 36 (I952).

${ }^{180}$ Such a proposal is reported by James Reston to have been made by "a high official of the United States Government," who said that it had been under discussion "quietly inside our own Government for six months ... . but this is so foreign to our normal way of doing business that we dare not mention. it in public." N.Y. Times, Dec. 2, 1958, p. 17, col. 3. 
system of cooperation between our Government and our individual business firms which would go far beyond the existing system of governmental controls upon private trade with communist countries, without, however, replacing private trade with state trading. It would involve, therefore, a readjustment of existing concepts of the relationship between business and government in the field of international trade; more specifically, it would involve the supplementing of the concept of government control of business by the concept of active cooperation between government and business in this field. Such a readjustment is required if we are to trade on competitive terms with countries which treat foreign trade as a governmental function. 